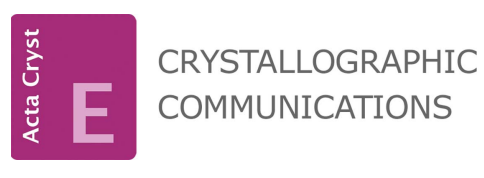

ISSN 2056-9890

Received 15 June 2020

Accepted 7 July 2020

Edited by J. Ellena, Universidade de Sâo Paulo, Brazil

Keywords: crystal structure; bivalent metal; $N$ benzoylglycine; $\mu_{2}$-bridging aqua ligand; isostructural; hydrogen bonding; interchain interaction.

CCDC references: 2014672; 2014671

Supporting information: this article has supporting information at journals.iucr.org/e

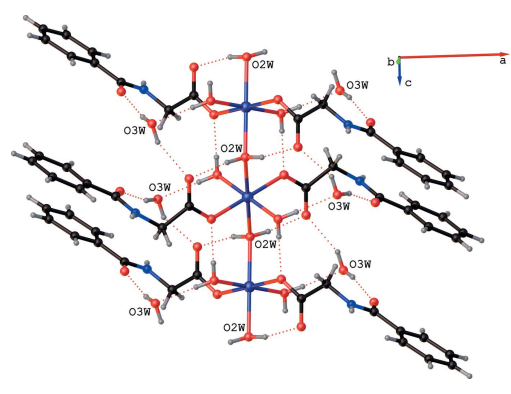

\section{Crystal structures of two isostructural bivalent metal $N$-benzoylglycinates}

\author{
Kedar U. Narvekar and Bikshandarkoil R. Srinivasan* \\ School of Chemical Sciences, Goa University PO, Goa 403206, India. *Correspondence e-mail: srini@unigoa.ac.in
}

The crystal structures of two coordination compounds of $N$-benzoylglycine, viz. catena-poly[[[diaquabis( $N$-benzoylglycinato)cobalt(II)]- $\mu$-aqua] dihydrate], $\left\{\left[\mathrm{Co}\left(\mathrm{C}_{9} \mathrm{H}_{8} \mathrm{NO}_{3}\right)_{2}\left(\mathrm{H}_{2} \mathrm{O}\right)_{3}\right] \cdot 2 \mathrm{H}_{2} \mathrm{O}\right\}_{n}, \mathbf{1}$, and catena-poly[[[diaquabis $(N$-benzoylglycinato)nickel(II) $]-\mu$-aqua] dihydrate], $\left\{\left[\mathrm{Ni}\left(\mathrm{C}_{9} \mathrm{H}_{8} \mathrm{NO}_{3}\right)_{2}\left(\mathrm{H}_{2} \mathrm{O}\right)_{3}\right] \cdot 2 \mathrm{H}_{2} \mathrm{O}\right\}_{n}, \boldsymbol{2}$, are described. The structures of $\mathbf{1}$ and $\mathbf{2}$ were reported previously [Morelock $e t$ al. (1979). J. Am. Chem. Soc. 101, 4858-4866] and redetermined in this work to determine the $\mathrm{H}$-atom coordinates. In the isostructural compounds, the central metal is located on an inversion centre and exhibits a distorted octahedral geometry. A pair of terminal aqua ligands disposed trans to each other and a pair of monodentate $\mathrm{N}$-benzoylglycinate ligands form the square base and account for four of the six vertices of the octahedron. A $\mu_{2}$-bridging aqua ligand links the bivalent metals into one-dimensional chains extending along the $c$-axis direction. The one-dimensional chains stabilized by $\mathrm{O}-\mathrm{H} \cdots \mathrm{O}$ hydrogen bonds are interlinked by $\mathrm{N}-\mathrm{H} \cdots \mathrm{O}$ and $\mathrm{C}-\mathrm{H} \cdots \mathrm{O}$ hydrogen-bonding interactions.

\section{Chemical context}

Hippuric acid known by other names such as $N$-benzoylglycine or benzoylaminoethanoic acid or $\mathrm{N}$-(benzenecarbon$\mathrm{yl}$ )glycine is a derivative of glycine and is produced in metabolic processes (Pero, 2010). Hence the benzoyl-substituted glycine, namely $\mathrm{N}$-benzoylglycine and its compounds, have been the subject of several investigations. The crystal structures of $N$-benzoylglycine and many of its derivatives are archived in the Cambridge Structural Database (CSD, version 5.40, update of September 2019; Groom et al., 2016). Unlike $\mathrm{N}$-benzoylglycine, which crystallizes in the non-centrosymmetric Sohncke space group $P 2{ }_{1} 2_{1} 2_{1}$, a majority of its derivatives are centrosymmetric solids. In most of these compounds, $N$-benzoylglycine functions as a charge-balancing ( $N$-benzoylglycinate) anion. In addition, the anion can also coordinate to a metal as observed in the title compounds. The $N$-benzoylglycinates of $\mathrm{Co}^{\mathrm{II}} \mathbf{1}$ and $\mathrm{Ni}^{\mathrm{II}} \mathbf{2}$ are some of the first examples of a series of $\alpha$-amino acid compounds of the firstrow transition-metal ions that exhibit low-dimensional magnetic properties (Morelock et al., 1979). Based on a study of the visible spectra and the magnetic properties, compound $\mathbf{1}$ was shown to be a metamagnet and $\mathbf{2}$ an antiferromagnet.

In the previous report, the title compounds $\mathbf{1}$ and $\mathbf{2}$ were prepared in an aqueous ethanolic medium by the reaction of the sodium salt of hippuric acid with the corresponding bivalent metal perchlorate (Morelock et al. 1979). The polymeric structure of $\mathbf{1}$ and $\mathbf{2}$ due to aqua bridging was described, but the hydrogen-atom coordinates were not reported. $\mathrm{N}$-Benzoylglycinates with a different stoichiometry repre- 
sented by the formula $M\left(\mathrm{C}_{9} \mathrm{H}_{8} \mathrm{NO}_{3}\right)_{2} \cdot 6 \mathrm{H}_{2} \mathrm{O}(M=\mathrm{Co}$ or $\mathrm{Ni})$ are also known in the literature (Marcotrigiano \& Pellacani, 1975). However, these were not structurally characterized. In the present work we have synthesized the title compounds by a direct acid-base reaction of cobalt carbonate (or nickel carbonate) with $\mathrm{N}$-benzoylglycine (hippuric acid) to obtain $\left[\mathrm{Co}\left(\mathrm{H}_{2} \mathrm{O}\right)_{3}\left(\mathrm{C}_{9} \mathrm{H}_{8} \mathrm{NO}_{3}\right)_{2}\right] \cdot 2 \mathrm{H}_{2} \mathrm{O}, \quad \mathbf{1}$, and $\left[\mathrm{Ni}\left(\mathrm{H}_{2} \mathrm{O}\right)_{3}\left(\mathrm{C}_{9} \mathrm{H}_{8^{-}}\right.\right.$ $\left.\left.\mathrm{NO}_{3}\right)_{2}\right] \cdot 2 \mathrm{H}_{2} \mathrm{O}, 2$, respectively. The infrared spectra of both compounds are nearly identical, indicating similar structures. A comparison of the spectra of $\mathbf{1}$ and $\mathbf{2}$ with that of the free ligand ( $N$-benzoylglycine) reveals notable changes in the profile of the spectra in the $3700-2750 \mathrm{~cm}^{-1}$ region. This can be explained by the presence of water molecules in $\mathbf{1}$ and $\mathbf{2}$, unlike in the free acid. $\mathrm{N}$-Benzoylglycine exhibits a strong signal at $\sim 1743 \mathrm{~cm}^{-1}$ assignable for the $-\mathrm{COOH}$ vibration, which is shifted to lower energies in $\mathbf{1}$ and $\mathbf{2}$ due to deprotonation (Fig. 1). Despite a slightly different synthetic methodology, the product obtained by us is the same as evidenced by the structural details of $\mathbf{1}$ and $\mathbf{2}$, which are in good agreement with the earlier work (Morelock et al. 1979) as shown below.

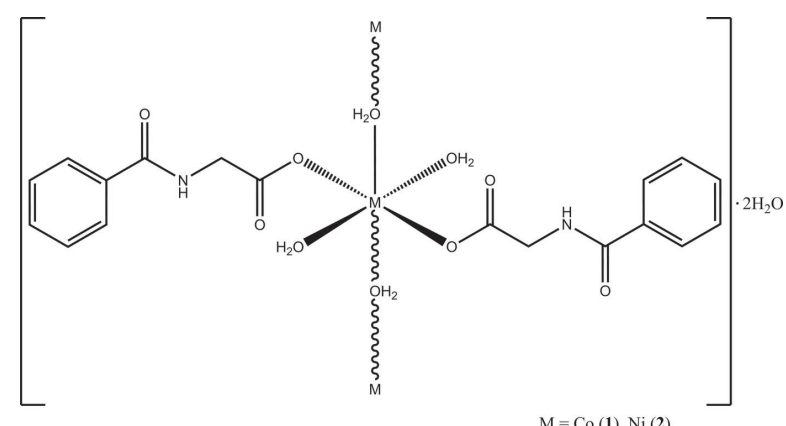

\section{Structural commentary}

The molecular structure of the isostructural compounds $\left[M\left(\mathrm{H}_{2} \mathrm{O}\right)_{3}\left(\mathrm{C}_{9} \mathrm{H}_{8} \mathrm{NO}_{3}\right)_{2}\right] \cdot 2 \mathrm{H}_{2} \mathrm{O}(M=\mathrm{Co} \mathbf{1}, M=\mathrm{Ni} 2)$ is illustrated in Fig. 2. Compounds $\mathbf{1}$ and $\mathbf{2}$ crystallize in the centrosymmetric monoclinic space group $C 2 / c$ with the central cobalt

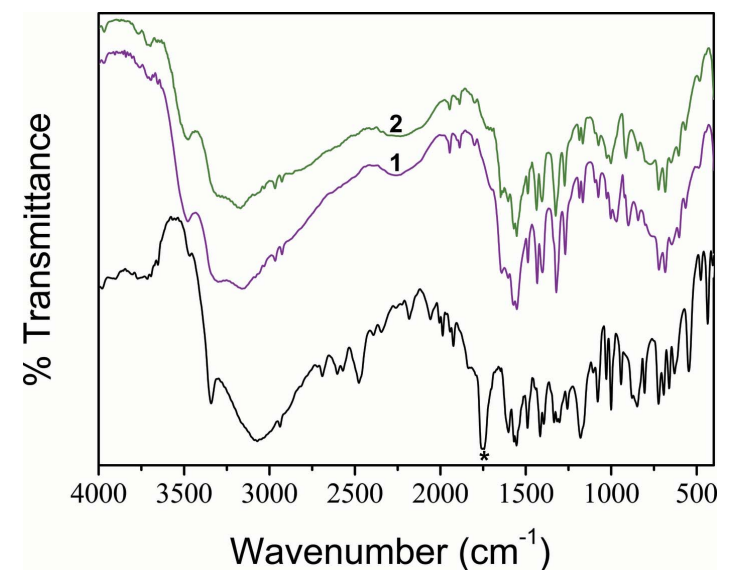

Figure 1

Infrared spectra of $\mathbf{1}, \mathbf{2}$ and $N$-benzoylglycine (bottom). * corresponds to the signal for $-\mathrm{COOH}$.
Table 1

Selected geometric parameters $\left(\AA,^{\circ}\right)$ for $\mathbf{1}$.

\begin{tabular}{lclc}
\hline $\mathrm{Co} 1-\mathrm{O} 2$ & $2.0563(15)$ & $\mathrm{Co} 1-\mathrm{O} 1 W^{\mathrm{i}}$ & $2.0622(17)$ \\
$\mathrm{Co} 1-\mathrm{O} 2^{\mathrm{i}}$ & $2.0563(15)$ & $\mathrm{Co} 1-\mathrm{O} 2 W^{\mathrm{i}}$ & $2.1899(9)$ \\
$\mathrm{Co} 1-\mathrm{O} 1 W$ & $2.0622(17)$ & $\mathrm{Co} 1-\mathrm{O} 2 W$ & $2.1899(9)$ \\
& & & \\
$\mathrm{O} 2-\mathrm{Co} 1-\mathrm{O} 2^{\mathrm{i}}$ & 180.0 & $\mathrm{O} 1 W-\mathrm{Co} 1-\mathrm{O} 2 W^{\mathrm{i}}$ & $90.55(7)$ \\
$\mathrm{O} 2-\mathrm{Co} 1-\mathrm{O} 1 W$ & $89.40(7)$ & $\mathrm{O} 1 W^{\mathrm{i}}-\mathrm{Co} 1-\mathrm{O} 2 W^{\mathrm{i}}$ & $89.45(7)$ \\
$\mathrm{O} 2^{\mathrm{i}}-\mathrm{Co} 1-\mathrm{O} 1 W$ & $90.60(7)$ & $\mathrm{O} 2-\mathrm{Co} 1-\mathrm{O} 2 W$ & $87.41(6)$ \\
$\mathrm{O} 2-\mathrm{Co} 1-\mathrm{O} 1 W^{\mathrm{i}}$ & $90.60(7)$ & $\mathrm{O} 2^{\mathrm{i}}-\mathrm{Co} 1-\mathrm{O} 2 W$ & $92.59(6)$ \\
$\mathrm{O} 2^{\mathrm{i}}-\mathrm{C} 1-\mathrm{O} 1 W^{\mathrm{i}}$ & $89.40(7)$ & $\mathrm{O} 1 W-\mathrm{Co} 1-\mathrm{O} 2 W$ & $89.45(7)$ \\
$\mathrm{O} 1 W-\mathrm{Co} 1-\mathrm{O} 1 W^{\mathrm{i}}$ & 180.0 & $\mathrm{O} 1 W^{\mathrm{i}}-\mathrm{Co} 1-\mathrm{O} 2 W$ & $90.55(7)$ \\
$\mathrm{O} 2-\mathrm{Co} 1-\mathrm{O} 2 W^{\mathrm{i}}$ & $92.59(6)$ & $\mathrm{O} 2 W^{\mathrm{i}}-\mathrm{Co} 1-\mathrm{O} 2 W$ & 180.0 \\
$\mathrm{O} 2^{\mathrm{i}}-\mathrm{Co} 1-\mathrm{O} 2 W^{\mathrm{i}}$ & $87.41(6)$ & $\mathrm{Co} 1^{\mathrm{ii}}-\mathrm{O} 2 W-\mathrm{Co} 1$ & $132.03(11)$ \\
\hline
\end{tabular}

Symmetry codes: (i) $-x+1,-y+1,-z+1$; (ii) $-x+1, y,-z+\frac{3}{2}$.

Table 2

Selected geometric parameters $\left(\AA{ }^{\circ}\right)$ for 2 .

\begin{tabular}{lclc}
\hline $\mathrm{Ni} 1-\mathrm{O} 2^{\mathrm{i}}$ & $2.029(2)$ & $\mathrm{Ni} 1-\mathrm{O} 1 W^{\mathrm{i}}$ & $2.041(2)$ \\
$\mathrm{Ni} 1-\mathrm{O} 2$ & $2.029(2)$ & $\mathrm{Ni} 1-\mathrm{O} 2 W^{\mathrm{i}}$ & $2.1450(12)$ \\
$\mathrm{Ni} 1-\mathrm{O} 1 W^{\mathrm{i}}$ & $2.041(2)$ & $\mathrm{Ni} 1-\mathrm{O} 2 W$ & $2.1450(12)$ \\
& & & \\
$\mathrm{O} 2^{\mathrm{i}}-\mathrm{Ni} 1-\mathrm{O} 2$ & $180.00(12)$ & $\mathrm{O} 1 W^{\mathrm{i}}-\mathrm{Ni} 1-\mathrm{O} 2 W^{\mathrm{i}}$ & $89.87(8)$ \\
$\mathrm{O} 2^{\mathrm{i}}-\mathrm{Ni} 1-\mathrm{O} 1 W^{\mathrm{i}}$ & $88.72(10)$ & $\mathrm{O} 1 W-\mathrm{Ni} 1-\mathrm{O} 2 W^{\mathrm{i}}$ & $90.13(8)$ \\
$\mathrm{O} 2-\mathrm{Ni} 1-\mathrm{O} 1 W^{\mathrm{i}}$ & $91.28(10)$ & $\mathrm{O} 2^{\mathrm{i}}-\mathrm{Ni} 1-\mathrm{O} 2 W$ & $92.73(8)$ \\
$\mathrm{O} 2^{\mathrm{i}}-\mathrm{Ni} 1-\mathrm{O} 1 W^{-}$ & $91.28(10)$ & $\mathrm{O} 2-\mathrm{Ni} 1-\mathrm{O} 2 W$ & $87.27(8)$ \\
$\mathrm{O} 2-\mathrm{Ni} 1-\mathrm{O} 1 W$ & $88.72(10)$ & $\mathrm{O} 1 W^{\mathrm{i}}-\mathrm{Ni} 1-\mathrm{O} 2 W$ & $90.13(8)$ \\
$\mathrm{O} 1 W^{\mathrm{i}}-\mathrm{Ni} 1-\mathrm{O} 1 W^{\mathrm{i}}$ & 180.0 & $\mathrm{O} 1 W_{-}-\mathrm{Ni} 1-\mathrm{O} 2 W$ & $89.87(8)$ \\
$\mathrm{O} 2^{\mathrm{i}}-\mathrm{Ni} 1-\mathrm{O} 2 W^{\mathrm{i}}$ & $87.27(8)$ & $\mathrm{O} 2 W^{\mathrm{i}}-\mathrm{Ni} 1-\mathrm{O} 2 W$ & 180.0 \\
$\mathrm{O} 2-\mathrm{Ni} 1-\mathrm{O} 2 W^{\mathrm{i}}$ & $92.73(8)$ & $\mathrm{Ni} 1-\mathrm{O} 2 W-\mathrm{Ni} 1^{\mathrm{ii}}$ & $134.02(15)$ \\
\hline
\end{tabular}

Symmetry codes: (i) $-x+1,-y+1,-z+1$; (ii) $-x+1, y,-z+\frac{1}{2}$.

(or nickel) ion located on an inversion centre. All of the atoms in both structures have been labelled so as to maintain parity for the ligand oxygen atoms and donor hydrogen and acceptor oxygen atoms in the hydrogen-bonding scheme. Other than the central metal, the structure consists of a unique terminal water $(\mathrm{O} 1 \mathrm{~W})$, a unique monodentate $N$-benzoylglycinate $(\mathrm{O} 2)$, a bridging aqua ligand $(\mathrm{O} 2 W)$ with the oxygen situated on a twofold axis and a non-ligated water $(\mathrm{O} 3 W)$, which constitute half of the formula unit of $\mathbf{1}$ or $\mathbf{2}$. In view of the special position of the central metal, the other half is generated by the application of inversion symmetry. The geometric parameters of the $\mathrm{N}$-benzoylglycinates are in the normal ranges and are in agreement with reported data (Natarajan et al., 2007). The metal-oxygen bond distances (Tables 1 and 2) scatter in a very narrow range [2.0563 (15) to 2.1899 (9) $\AA$ in $\mathbf{1}$; 2.029 (2) to $2.1450(12) \AA$ in 2]. In both compounds, the carboxylate oxygen $(\mathrm{O} 2)$ of the $N$-benzoylglycinate makes the

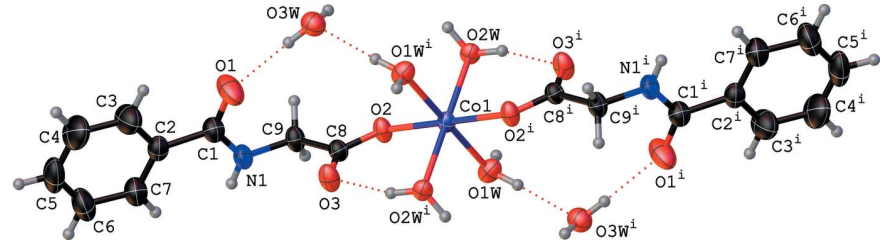

Figure 2

The molecular structure of $\mathbf{1}$ showing the crystallographic labelling with displacement ellipsoids drawn at $50 \%$ probability level. Hydrogen atoms are drawn as spheres of arbitrary radius. Intramolecular hydrogen bonds are shown as red dotted lines. Symmetry code: (i) $1-x, 1-y, 1-z$. 
Table 3

Hydrogen-bond geometry $\left(\AA{ }^{\circ}\right)$ for $\mathbf{1}$.

\begin{tabular}{lllll}
\hline$D-\mathrm{H} \cdots A$ & $D-\mathrm{H}$ & $\mathrm{H} \cdots A$ & $D \cdots A$ & $D-\mathrm{H} \cdots A$ \\
\hline $\mathrm{O} 1 W-\mathrm{H} 1 W A \cdots \mathrm{O} 2^{\text {ii }}$ & $0.78(3)$ & $1.93(3)$ & $2.714(2)$ & $176(3)$ \\
$\mathrm{O} 1 W-\mathrm{H} 1 W B \cdots \mathrm{O} 3 W^{\text {i }}$ & $0.85(3)$ & $1.93(3)$ & $2.780(3)$ & $178(3)$ \\
$\mathrm{O} W-\mathrm{H} 2 W \cdots \mathrm{O} 3^{\text {iii }}$ & $0.88(3)$ & $1.80(3)$ & $2.6576(18)$ & $163(3)$ \\
$\mathrm{C} 9-\mathrm{H} 9 B \cdots 3^{\text {iv }}$ & 0.97 & 2.51 & $3.481(3)$ & 178 \\
$\mathrm{~N} 1-\mathrm{H} 1 \cdots \mathrm{O} 3 W^{\mathrm{v}}$ & $0.83(3)$ & $2.13(3)$ & $2.880(3)$ & $149(2)$ \\
$\mathrm{O} 3 W-\mathrm{H} 3 W A \cdots \mathrm{O} 1$ & $0.83(4)$ & $1.90(4)$ & $2.708(3)$ & $164(3)$ \\
$\mathrm{O} 3 W-\mathrm{H} 3 W B \cdots \mathrm{O} 3^{\text {iii }}$ & $0.84(3)$ & $2.12(3)$ & $2.873(3)$ & $149(3)$ \\
\hline
\end{tabular}

Symmetry codes: (i) $-x+1,-y+1,-z+1$; (ii) $-x+1, y,-z+\frac{3}{2}$; (iii) $x,-y+1, z+\frac{1}{2}$; (iv) $x,-y+2, z+\frac{1}{2}$; (v) $x, y+1, z$.

shortest $M-\mathrm{O}$ bond length while the longest $M-\mathrm{O}$ bond distance is observed for the bridging aqua ligand $(\mathrm{O} 2 W)$. Both compounds exhibit ideal values for the trans $\mathrm{O}-M-\mathrm{O}$ bond angles while the cis $\mathrm{O}-M-\mathrm{O}$ angles show a slight deviation [87.41 (6) to $92.59(6)^{\circ}$ in $\mathbf{1} ; 87.27(8)$ to $92.73(8)^{\circ}$ in 2 ] indicating a slight distortion of the $\left\{\mathrm{MO}_{6}\right\}$ octahedron (Tables 1 and 2). The difference $\Delta$ between the longest and the shortest $M-\mathrm{O}$ bonds can be considered as a measure of the distortion from ideal geometry and is $0.1336(0.18)$ and $0.114(0.12) \AA$ for compounds $\mathbf{1}$ and $\mathbf{2}$, respectively. The values in brackets are the difference $\Delta$ calculated from the reported bond distances of the earlier study. It is interesting to note that the same trend is observed with $\left\{\mathrm{CoO}_{6}\right\}$ octahedron being slightly more distorted. The central metal exhibits hexa coordination and is bonded to two terminal aqua ligands $\left(\mathrm{O} 1 W, \mathrm{O} 1 W^{\mathrm{i}}\right)$ [symmetry code: (i) $-x+1,-y+1,-z+1]$ disposed trans to each other and two monodentate $N$-benzoylglycinate $\left(\mathrm{O} 2, \mathrm{O} 2^{\mathrm{i}}\right)$ ligands accounting for the square base of the octahedron. The $\mu_{2^{-}}$ bridging binding mode of the aqua ligand $(\mathrm{O} 2 W)$ makes two axial bonds trans to each other completing the octahedral geometry around the central metal. The bridging binding mode results in the formation of a one-dimensional chain structure extending along the $c$-axis direction (Fig. 3). In the infinite chain, the observed $M \cdots M$ separations of 4.0015 (2) $\AA$

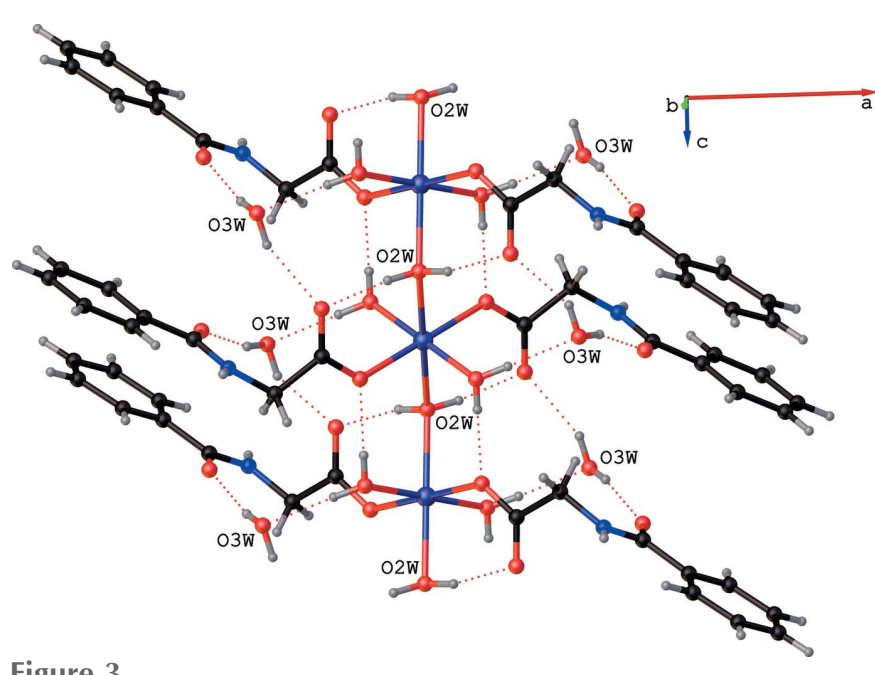

Figure 3

A portion of the one-dimensional chain formed by the bridging bidentate water molecules $(\mathrm{O} 2 \mathrm{~W})$, which extends the structure of $\mathbf{1}$ along the $c$-axis direction. The dotted red lines correspond to $\mathrm{O}-\mathrm{H} \cdots \mathrm{O}$ hydrogen bonds.
Table 4

Hydrogen-bond geometry $\left(\AA,^{\circ}\right)$ for 2 .

\begin{tabular}{lllll}
\hline$D-\mathrm{H} \cdots A$ & $D-\mathrm{H}$ & $\mathrm{H} \cdots A$ & $D \cdots A$ & $D-\mathrm{H} \cdots A$ \\
\hline $\mathrm{O} 1 W-\mathrm{H} 1 W A \cdots \mathrm{O} 2^{\mathrm{ii}}$ & $0.90(5)$ & $1.82(5)$ & $2.726(3)$ & $174(5)$ \\
$\mathrm{O} 1 W-\mathrm{H} 1 W B \cdots \mathrm{O} 3 W^{\mathrm{i}}$ & $0.81(5)$ & $1.97(5)$ & $2.783(4)$ & $176(5)$ \\
$\mathrm{O} W-\mathrm{H} 2 W \cdots 3^{\mathrm{i}}$ & $0.77(4)$ & $1.88(4)$ & $2.634(3)$ & $167(4)$ \\
$\mathrm{C} 9-\mathrm{H} 9 B \cdots 3^{\mathrm{iii}}$ & 0.97 & 2.50 & $3.465(4)$ & 176 \\
$\mathrm{~N} 1-\mathrm{H} 1 \cdots \mathrm{O} 3 W^{\text {iv }}$ & $0.93(5)$ & $2.04(5)$ & $2.888(4)$ & $151(4)$ \\
$\mathrm{O} W-\mathrm{H} 3 W B \cdots \mathrm{O} 3^{\mathrm{v}}$ & $0.86(6)$ & $2.10(6)$ & $2.858(4)$ & $147(5)$ \\
$\mathrm{O} W-\mathrm{H} 3 W A \cdots \mathrm{O} 1$ & $0.81(9)$ & $1.92(9)$ & $2.697(4)$ & $159(8)$ \\
\hline
\end{tabular}

Symmetry codes: (i) $-x+1,-y+1,-z+1$; (ii) $-x+1, y,-z+\frac{1}{2}$; (iii) $x,-y+2, z-\frac{1}{2}$; (iv) $x, y+1, z$; (v) $x,-y+1, z-\frac{1}{2}$.

or 3.9492 (8) $\AA$ in $\mathbf{1}$ or $\mathbf{2}$, respectively, are in very good agreement with the earlier work (Morelock et al. 1979). The $M-\mathrm{O} 2 W-M^{\mathrm{ii}}$ bond angle $\theta$ for $\mathbf{1}$ [symmetry code: (ii) $-x+1$, $y,-z+\frac{3}{2}$ ] and $\mathbf{2}$ [symmetry code: (ii) $-x+1, y,-z+\frac{1}{2}$ ] are 132.03 (11) and $134.02(15)^{\circ}$ for $\mathbf{1}$ and $\mathbf{2}$, respectively, which follow the earlier trend with the reported $\theta$ values being 128.3 and $137.2^{\circ}$ (Morelock et al. 1979). The $\Theta$ value is marginally higher for 2 and is accompanied by a shorter Ni1-O $2 W$ bond distance of 2.1450 (12) $\AA$. The decreasing bond distance is attributed to increasing orbital overlap, explaining the larger superexchange in $\mathbf{2}$ leading to spin-pairing.

\section{Supramolecular features}

The isostructural compounds $\mathbf{1}$ and $\mathbf{2}$ exhibit several noncovalent interactions, namely $\mathrm{O}-\mathrm{H} \cdots \mathrm{O}, \mathrm{N}-\mathrm{H} \cdots \mathrm{O}$ and $\mathrm{C}-$ $\mathrm{H}$... O hydrogen bonds (Tables 3 and 4) in their supramolecular structures. All of the hydrogen atoms attached to the water molecules, the hydrogen atom bonded to nitrogen $\mathrm{N} 1$ and a hydrogen atom attached to the methylene carbon C9 function as hydrogen donors and four of the six oxygen atoms, namely $\mathrm{O} 1, \mathrm{O} 2, \mathrm{O} 3$ and $\mathrm{O} 3 W$, function as hydrogen acceptors.

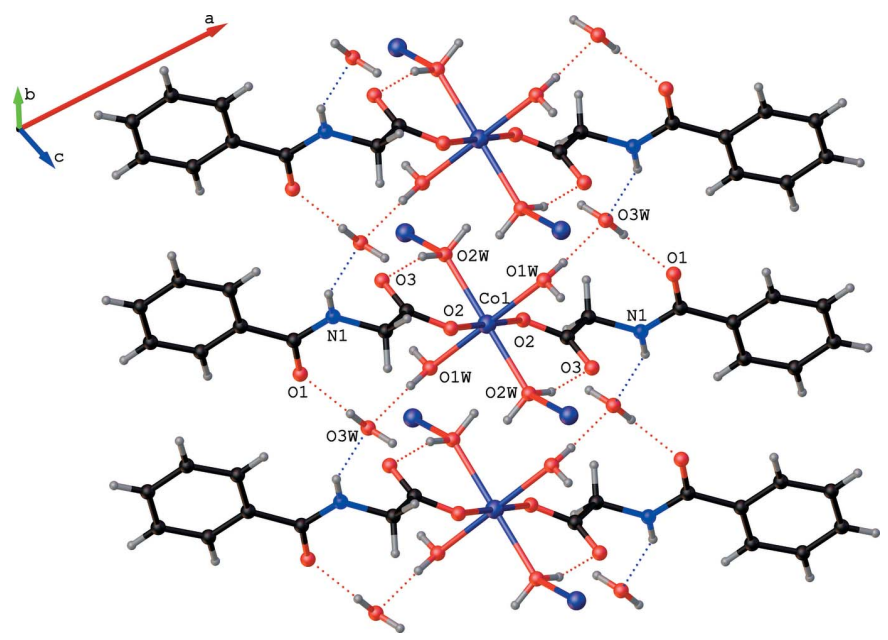

Figure 4

Non-ligated water $(\mathrm{O} 3 W)$ interlinks adjacent chains via $\mathrm{N}-\mathrm{H} \cdots \mathrm{O}$ hydrogen bonds (shown as blue dotted lines). Intrachain $\mathrm{O}-\mathrm{H} \cdots \mathrm{O}$ hydrogen bonds are shown as red dotted lines. For clarity, the terminal ligands are displayed only for the metal in the middle of each chain. 
Table 5

Comparative structural chemistry of bivalent metal $\mathrm{N}$-benzoylglycinates.

$\mathrm{CN}=$ coordination number of metal, $\mathrm{C}_{9} \mathrm{H}_{9} \mathrm{NO}_{3}=N$-benzoylglycine, $\mathrm{C}_{9} \mathrm{H}_{8} \mathrm{NO}_{3}=N$-benzoylglycinate

\begin{tabular}{|c|c|c|c|c|c|}
\hline Compound & Space group & $\mathrm{CN}$ & Binding mode & Dimensionality & Refcode \\
\hline $\mathrm{C}_{9} \mathrm{H}_{9} \mathrm{NO}_{3}$ & $P 2_{1} 2_{1} 2_{1}$ & - & - & monomer & HIPPAC \\
\hline$\left[\mathrm{Ca}\left(\mathrm{H}_{2} \mathrm{O}\right)_{2}\left(\mathrm{C}_{9} \mathrm{H}_{8} \mathrm{NO}_{3}\right)_{2}\right] \cdot \mathrm{H}_{2} \mathrm{O}$ & $P 2_{1} / c$ & 8 & $\mu_{2}$-tridentate & one-dimensional & ANEDON \\
\hline$\left[\mathrm{Ba}_{2}\left(\mathrm{H}_{2} \mathrm{O}\right)_{3}\left(\mathrm{C}_{9} \mathrm{H}_{8} \mathrm{NO}_{3}\right)_{4}\right]$ & $P \overline{1}$ & 9,10 & $\mu_{3}$-tridentate, $\mu_{3}$-tetradentate & two-dimensional & HIFFIM \\
\hline$\left[\mathrm{Co}\left(\mathrm{H}_{2} \mathrm{O}\right)_{3}\left(\mathrm{C}_{9} \mathrm{H}_{8} \mathrm{NO}_{3}\right)_{2}\right] \cdot 2 \mathrm{H}_{2} \mathrm{O}$ & $C 2 / c$ & 6 & monodentate & one-dimensional & COHIPP10, this work \\
\hline$\left[\mathrm{Ni}\left(\mathrm{H}_{2} \mathrm{O}\right)_{3}\left(\mathrm{C}_{9} \mathrm{H}_{8} \mathrm{NO}_{3}\right)_{2}\right] \cdot 2 \mathrm{H}_{2} \mathrm{O}$ & $C 2 / c$ & 6 & monodentate & one-dimensional & ANIHIP, this work \\
\hline$\left[\mathrm{Cu}_{2}\left(\mathrm{H}_{2} \mathrm{O}\right)_{4}\left(\mathrm{C}_{9} \mathrm{H}_{8} \mathrm{NO}_{3}\right)_{4}\right] \cdot 2 \mathrm{H}_{2} \mathrm{O}$ & $P 2_{1} / c$ & 5,5 & monodentate, $\mu_{2}$-monoatomic & dimer & CUHIPT \\
\hline$\left[\mathrm{Zn}\left(\mathrm{H}_{2} \mathrm{O}\right)_{3}\left(\mathrm{C}_{9} \mathrm{H}_{8} \mathrm{NO}_{3}\right)_{2}\right] \cdot 2 \mathrm{H}_{2} \mathrm{O}$ & $P 1$ & 5 & monodentate & monomer & BIZFUL \\
\hline
\end{tabular}

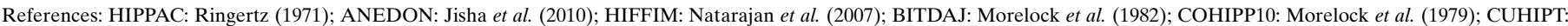
Brown \& Trefonas (1973); BIZFUL: Grewe et al. (1982); TEZMOA: Battistuzzi et al. (1996).

All of the $\mathrm{O}-\mathrm{H} \cdots \mathrm{O}$ hydrogen bonds are intrachain interactions (Fig. 3). The non-ligated water $\mathrm{O} 3 \mathrm{~W}$ interlinks adjacent chains with the aid of a single short $\mathrm{N} 1-\mathrm{H} 1 \cdots \mathrm{O} 3 W$ interaction at $\mathrm{H} \cdots A$ distances of 2.13 (3) and 2.04 (5) $\AA$ in $\mathbf{1}$ and 2 , respectively, accompanied by $D-\mathrm{H} \cdots A$ angles of 149 (2) and $151(4)^{\circ}$ (Fig. 4). A short C9-H9B . OO $3^{\text {iv }}$ interaction at a $\mathrm{H} \cdots A$ distance $2.51 \AA$ in $\mathbf{1}(2.50 \AA$ in 2) accompanied by $D-\mathrm{H} \cdots A$ angle of $177.9^{\circ}$ in $\mathbf{1},\left(176.4^{\circ}\right.$ in 2$)$ links the $\mathrm{H} 9 B$ atom of a methylene group of $N$-benzoylglycinate in one chain with the $\mathrm{O} 3$ atom of a symmetry-related $\mathrm{N}$ benzoylglycinate in a neighboring chain functioning as a hydrogen acceptor (Fig. 5). These interchain hydrogenbonding interactions serve to hold the chains together along the $b$ axis, forming a layer of chains in the $b c$ plane. Thus, the findings of our present study once again support the original findings, namely compounds $\mathbf{1}$ and $\mathbf{2}$ are unique examples of psuedo one-dimensional (1D) magnetic materials in which three-dimensional magnetic ordering was predicted not to occur until $T \rightarrow 0 \mathrm{~K}$. In addition to the hydrogen-bonding

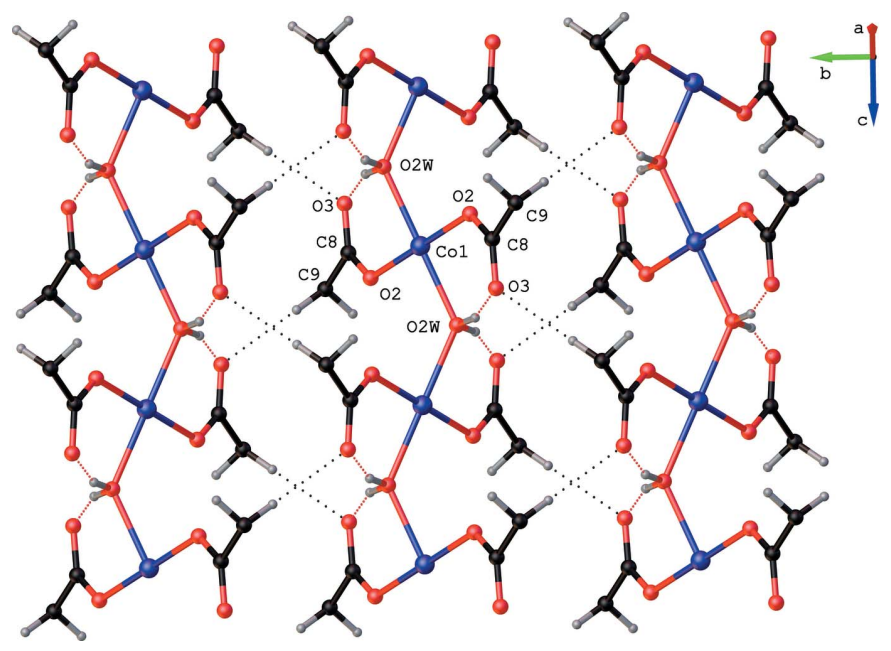

Figure 5

The $\mathrm{C} 9-\mathrm{H} 9 B \cdots \mathrm{O}^{\text {iv }}$ interaction (shown as black dotted lines) links the $\mathrm{H} 9 B$ atom in one chain with the $\mathrm{O} 3$ atom of a neighbouring chain. Intrachain $\mathrm{O}-\mathrm{H} \cdots \mathrm{O}$ hydrogen bonds are shown as red dotted lines. For clarity, only the $-\mathrm{CH}_{2}-\mathrm{COO}$ group of $\mathrm{N}$-benzoylglycinate is displayed. The terminal aqua ligands and the non-ligated water are omitted. interactions, $\mathbf{1}$ and $\mathbf{2}$ exhibit $\pi-\pi$ stacking interactions (Hunter \& Sanders, 1990). For the analysis of short ring interactions, the program PLATON (Spek, 2020) was used. The ring centroid-centroid distances $(C g \cdots C g)$ between the adjacent benzene rings in $\mathbf{1}$ and $\mathbf{2}$ are found to be 4.0435 (2) and 3.9807 (5) ̊, respectively. It has been reported that stacking interactions can exist at very long $C g \cdots C g$ distances of up to $7 \AA$ (Ninković et al., 2011). Hence, the observed $C g \cdots C g$ distances can be attributed to the $\pi-\pi$ stacking of the benzene rings.

\section{Database survey}

The Cambridge Structural Database (CSD, version 5.40, update of September 2019; Groom et al., 2016) lists several structurally characterized organic and metal-organic compounds of $N$-benzoylglycine. Since the first report on the crystal structure of $N$-benzoylglycine (Ringertz, 1971), several compounds of $N$-benzoylglycine have been structurally characterized. Excepting an example of a 1:1 co-crystal of $N$-benzoylglycine, namely glibenclamide hippuric acid (Goyal et al., 2017), the structures of thirty two compounds containing the monoanionic $N$-benzoylglycinate were retrieved from the CSD (Groom et al., 2016). Three of these do not contain any metal and are charge-balanced by organic cations (Görbitz \& Sagstuen, 2004; Chadha et al., 2016; John et al., 2018). Of the twenty nine examples of $N$-benzoylglycinates with metalorganic cations, eight contain bivalent metal (Table 5) and aqua ligands. In this work, a comparative study of bivalent metal $N$-benzoylglycinates containing only aqua ligands has been undertaken. It is interesting to note that all of these compounds contain coordinated water molecules. In this list of compounds, excepting the $N$-benzoylglycinate of $\mathrm{Zn}^{\mathrm{II}}$ (Grewe et al., 1982), the rest are all centrosymmetric. In all eight compounds, the $N$-benzoylglycinate coordinates to the metal only through the carboxylate oxygen atoms. In five of these, including the title compounds, $N$-benzoylglycinate functions as a monodentate ligand. The bridging binding mode in the $N$-benzoylglycinates of $\mathrm{Ca}^{\mathrm{II}}$ (Jisha et al., 2010), $\mathrm{Ba}^{\mathrm{II}}$ (Natarajan et al. 2007), $\mathrm{Cu}^{\mathrm{II}}$ (Brown \& Trefonas, 1973) and $\mathrm{Pb}^{\mathrm{II}}$ (Battistuzzi et al., 1996) can explain the polymeric nature of these 
Table 6

Experimental details.

1

Crystal data

Chemical formula

$M_{\text {r }}$

Crystal system, space group

Temperature $(\mathrm{K})$

$a, b, c(\AA)$

$\beta\left({ }^{\circ}\right)$

$V\left(\AA^{3}\right)$

Z

Radiation type

$\mu\left(\mathrm{mm}^{-1}\right)$

Crystal size (mm)

Data collection

Diffractometer

Absorption correction

$T_{\min }, T_{\max }$

No. of measured, independent and

observed $[I>2 \sigma(I)]$ reflections

$R_{\text {int }}$

$(\sin \theta / \lambda)_{\max }\left(\AA^{-1}\right)$

Refinement

$R\left[F^{2}>2 \sigma\left(F^{2}\right)\right], w R\left(F^{2}\right), S$

No. of reflections

No. of parameters

$\mathrm{H}$-atom treatment

$\Delta \rho_{\max }, \Delta \rho_{\min }\left(\mathrm{e} \AA^{-3}\right)$

\author{
$\left[\mathrm{Co}\left(\mathrm{C}_{9} \mathrm{H}_{8} \mathrm{NO}_{3}\right)_{2}\left(\mathrm{H}_{2} \mathrm{O}\right)_{3}\right] \cdot 2 \mathrm{H}_{2} \mathrm{O}$ \\ 505.34 \\ Monoclinic, $C 2 / c$ \\ 293 \\ 40.843 (2), 6.9072 (4), 8.0031 (4) \\ $91.891(2)$ \\ $2256.6(2)$ \\ 4 \\ Mo $K \alpha$ \\ 0.82 \\ $0.35 \times 0.27 \times 0.04$
}

Bruker D8 Quest Eco

Numerical (SADABS; Krause et al., 2015)

$0.610,0.746$

15061, 2799, 2070

0.046

0.666

$0.037,0.086,1.08$

2799

171

$\mathrm{H}$ atoms treated by a mixture of independent and constrained refinement $0.39,-0.43$
2

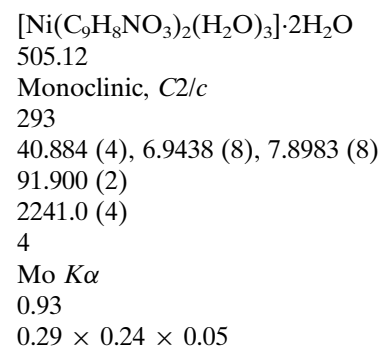

Bruker D8 Quest Eco

Numerical (SADABS; Krause et al., 2015)

$0.608,0.746$

17095, 3392, 2995

0.036

0.714

$0.056,0.151,1.15$

3392

174

$\mathrm{H}$ atoms treated by a mixture of independent and constrained refinement $1.24,-0.76$

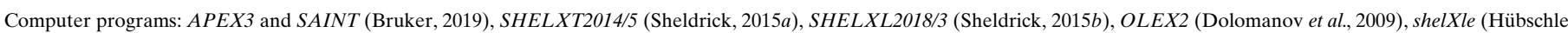
et al., 2011) and publCIF (Westrip, 2010).

compounds, excepting the $\mathrm{Cu}^{\mathrm{II}}$ which is a dimer. The structure of the dimeric copper compound (Refcode CUHIPT; Brown \& Trefonas, 1973) contains both a monodentate as well as a monoatomic bridging $N$-benzoylglycinate. It is interesting to note that the dinuclear $\mathrm{Cu}^{\mathrm{II}}$ compound of $N$-benzoylglycine does not adopt the paddle-wheel structure. The $N$-benzoylglycinate of $\mathrm{Fe}^{\mathrm{II}}$ (Morelock et al., 1982) is also isostructural with the title compounds and is a $1 \mathrm{D}$ polymer. It is interesting to note that in the three isostructural $\mathrm{N}$-benzoylglycinates of $3 d$ metals, an aqua ligand functions as a bridging ligand to extend the structure, and not the $N$-benzoylglycinate.

\section{Synthesis and crystallization}

For the synthesis of $\mathbf{1}, N$-benzoylglycine $(1.792 \mathrm{~g}, 10 \mathrm{mmol})$ taken in distilled water $(50 \mathrm{~mL})$ was heated with stirring to obtain a clear solution. Into this, $\mathrm{CoCO}_{3}(0.595 \mathrm{~g}, 5 \mathrm{mmol})$ was added in small portions. Brisk effervescence was observed accompanied by the dissolution of the insoluble carbonate, resulting in a pink-coloured solution. When most of the carbonate had dissolved, a small amount $(\sim 25 \mathrm{mg})$ of the carbonate was added and the heating continued for a further hour. The hot reaction mixture was filtered and the clear pink filtrate was left undisturbed for crystallization. The crystals obtained after a few days were isolated by filtration and dried in air, yield $=90 \%$. A similar procedure was employed for 2 using nickel carbonate instead of cobalt carbonate and the filtrate obtained was light green. Crystals were isolated as before, yield $=80 \%$.

\section{Refinement}

Crystal data, data collection and structure refinement details are summarized in Table 6. $\mathrm{O}$ - and $\mathrm{N}$-bound $\mathrm{H}$ atoms were freely refined. C-bound hydrogen atoms were placed at calculated positions $\mathrm{C}-\mathrm{H}=0.93-0.97 \AA$ ) and refined isotropically $\left[U_{\text {iso }}(\mathrm{H})=1.2 U_{\text {eq }}(\mathrm{C})\right.$. using a riding-atom model.

\section{Funding information}

KUN acknowledges the University Grants Commission (UGC), New Delhi, for the sanction of a UGC Basic Scientific Research Fellowship. BRS acknowledges the Department of Science \& Technology (DST), New Delhi, for the sanction of a Bruker D8 Quest Eco single crystal X-ray diffractometerunder the DST-FIST program.

\section{References}

Battistuzzi, G., Borsari, M., Menabue, L., Saladini, M. \& Sola, M. (1996). Inorg. Chem. 35, 4239-4247.

Brown, J. N. \& Trefonas, L. M. (1973). Inorg. Chem. 12, 1730-1733.

Bruker (2019). APEX3 and SAINT. Bruker AXS Inc., Madison, Wisconsin, USA.

Chadha, R., Singh, P., Khullar, S. \& Mandal, S. K. (2016). Cryst. Growth Des. 16, 4960-4967. 
Dolomanov, O. V., Bourhis, L. J., Gildea, R. J., Howard, J. A. K. \& Puschmann, H. (2009). J. Appl. Cryst. 42, 339-341.

Görbitz, C. H. \& Sagstuen, E. (2004). Acta Cryst. E60, o1945o1947.

Goyal, P., Rani, D. \& Chadha, R. (2018). Cryst. Growth Des. 18, 105118.

Grewe, H., Udupa, M. R. \& Krebs, B. (1982). Inorg. Chim. Acta, 63, 119-124.

Groom, C. R., Bruno, I. J., Lightfoot, M. P. \& Ward, S. C. (2016). Acta Cryst. B72, 171-179.

Hübschle, C. B., Sheldrick, G. M. \& Dittrich, B. (2011). J. Appl. Cryst. 44, 1281-1284.

Hunter, C. A. \& Sanders, J. K. M. (1990). J. Am. Chem. Soc. 112, 5525-5534.

Jisha, K. R., Suma, S. \& Sudarsanakumar, M. R. (2010). Polyhedron, 29, 3164-3169.

John, J. S., Arumanayagam, T., Murugakoothan, P., Sajan, D., Joy, N. \& Philip, R. (2018). CSD Communication (CCDC code 1863868). CCDC, Cambridge, England.
Krause, L., Herbst-Irmer, R., Sheldrick, G. M. \& Stalke, D. (2015). J. Appl. Cryst. 48, 3-10.

Marcotrigiano, G. \& Pellacani, G. C. (1975). Inorg. Nucl. Chem. Lett. 11, 643-648.

Morelock, M. M., Good, M. L., Trefonas, L. M., Karraker, D., Maleki, L., Eichelberger, H. R., Majeste, R. \& Dodge, J. (1979). J. Am. Chem. Soc. 101, 4858-4866.

Morelock, M. M., Good, M. L., Trefonas, L. M., Majeste, R. \& Karraker, D. G. (1982). Inorg. Chem. 21, 3044-3050.

Natarajan, S., Dhas, S. A. M. B., Suresh, J. \& Krishnakumar, R. V. (2007). Acta Cryst. E63, m1408-m1410.

Ninković, D. B., Janjić, G. V., Veljković, D. Ž., Sredojević, D. N. \& Zarić, S. D. (2011). Chem. Phys. Chem. 12, 351-351.

Pero, R. W. (2010). Curr. Clin. Pharmacol. 5, 67-73.

Ringertz, H. (1971). Acta Cryst. B27, 285-291.

Sheldrick, G. M. (2015a). Acta Cryst. A71, 3-8.

Sheldrick, G. M. (2015b). Acta Cryst. C71, 3-8.

Spek, A. L. (2020). Acta Cryst. E76, 1-11.

Westrip, S. P. (2010). J. Appl. Cryst. 43, 920-925. 


\section{supporting information}

Acta Cryst. (2020). E76, 1260-1265 [https://doi.org/10.1107/S2056989020009287]

\section{Crystal structures of two isostructural bivalent metal $\mathrm{N}$-benzoylglycinates}

\section{Kedar U. Narvekar and Bikshandarkoil R. Srinivasan}

\section{Computing details}

For both structures, data collection: APEX3 (Bruker, 2019); cell refinement: SAINT (Bruker, 2019); data reduction: SAINT (Bruker, 2019); program(s) used to solve structure: SHELXT2014/5 (Sheldrick, 2015a); program(s) used to refine structure: SHELXL2018/3 (Sheldrick, 2015b); molecular graphics: OLEX2 (Dolomanov et al., 2009), shelXle (Hübschle et al., 2011); software used to prepare material for publication: publCIF (Westrip, 2010).

catena-Poly[[[diaquabis(N-benzoylglycinato)cobalt(II)]- $\mu$-aqua] dihydrate] (1)

Crystal data

$\left[\mathrm{Co}\left(\mathrm{C}_{9} \mathrm{H}_{8} \mathrm{NO}_{3}\right)_{2}\left(\mathrm{H}_{2} \mathrm{O}\right)_{3}\right] \cdot 2 \mathrm{H}_{2} \mathrm{O}$

$M_{r}=505.34$

Monoclinic, $C 2 / c$

$a=40.843$ (2) $\AA$

$b=6.9072(4) \AA$

$c=8.0031(4) \AA$

$\beta=91.891(2)^{\circ}$

$V=2256.6(2) \AA^{3}$

$Z=4$

Data collection

Bruker D8 Quest Eco diffractometer

Radiation source: Sealed Tube $\varphi$ and $\omega$ scans Absorption correction: numerical

(SADABS; Krause et al., 2015)

$T_{\min }=0.610, T_{\max }=0.746$

15061 measured reflections

Refinement

Refinement on $F^{2}$

Least-squares matrix: full

$R\left[F^{2}>2 \sigma\left(F^{2}\right)\right]=0.037$

$w R\left(F^{2}\right)=0.086$

$S=1.08$

2799 reflections

171 parameters

0 restraints
$F(000)=1052$

$D_{\mathrm{x}}=1.487 \mathrm{Mg} \mathrm{m}^{-3}$

Mo $K \alpha$ radiation, $\lambda=0.71073 \AA$

Cell parameters from 4616 reflections

$\theta=3.0-28.0^{\circ}$

$\mu=0.82 \mathrm{~mm}^{-1}$

$T=293 \mathrm{~K}$

Plate, pink

$0.35 \times 0.27 \times 0.04 \mathrm{~mm}$

2799 independent reflections

2070 reflections with $I>2 \sigma(I)$

$R_{\text {int }}=0.046$

$\theta_{\text {max }}=28.3^{\circ}, \theta_{\min }=3.0^{\circ}$

$h=-54 \rightarrow 54$

$k=-9 \rightarrow 9$

$l=-10 \rightarrow 10$

Hydrogen site location: mixed

$\mathrm{H}$ atoms treated by a mixture of independent and constrained refinement

$w=1 /\left[\sigma^{2}\left(F_{\mathrm{o}}^{2}\right)+(0.0214 P)^{2}+3.6234 P\right]$

where $P=\left(F_{\mathrm{o}}^{2}+2 F_{\mathrm{c}}{ }^{2}\right) / 3$

$(\Delta / \sigma)_{\max }<0.001$

$\Delta \rho_{\max }=0.39 \mathrm{e} \AA^{-3}$

$\Delta \rho_{\min }=-0.42 \mathrm{e} \AA^{-3}$ 


\section{Special details}

Geometry. All esds (except the esd in the dihedral angle between two 1.s. planes) are estimated using the full covariance matrix. The cell esds are taken into account individually in the estimation of esds in distances, angles and torsion angles; correlations between esds in cell parameters are only used when they are defined by crystal symmetry. An approximate (isotropic) treatment of cell esds is used for estimating esds involving l.s. planes.

Refinement. Suitable single crystals were selected under a polarizing microscope in HR2-643 parabar 10312 oil from Hampton Research. The crystal was mounted on a 20 micron 0.4-0.5 mm HR4-953 Mounted Cryoloops loop from Hampton Research and transferred to the Bruker D8 Quest Eco diffractometer. Reflections harvested from two sets of 12, $0.5^{\circ} \varphi$ scans were used to determine unit-cell parameters and was used to determine the data-collection strategy. Unit-cell parameters were refined using reflections harvested from the data collection. The frames were integrated with the Bruker SAINT software package using a narrow-frame algorithm. The integration of the data using a monoclinic unit cell yielded a total of 15061 reflections to a maximum $\theta$ angle of $28.26^{\circ}(0.75 \AA$ resolution) for 1 and 17095 reflections to a maximum $\theta$ angle of $30.52^{\circ}(0.70 \AA$ resolution $)$ for 2 . All data were corrected for Lorentz and polarization effects and subsequently scaled. A numerical absorption correction was performed by SADABS (Krause et al., 2015). The space group was determined and the structures were solved using the intrinsic phasing method (Bruker, 2019; Sheldrick, 2008). The structures were refined in APEX3 v2019.1-0 by SHELXL (Sheldrick, 2015).

Fractional atomic coordinates and isotropic or equivalent isotropic displacement parameters $\left(\AA^{2}\right)$

\begin{tabular}{|c|c|c|c|c|}
\hline & $x$ & $y$ & $z$ & $U_{\text {iso }} * / U_{\text {eq }}$ \\
\hline Co1 & 0.500000 & 0.500000 & 0.500000 & $0.02504(12)$ \\
\hline $\mathrm{O} 1 \mathrm{~W}$ & $0.53443(4)$ & 0.6984 & $0.5847(2)$ & $0.0359(4)$ \\
\hline H1WA & $0.5349(7)$ & $0.699(4)$ & $0.682(4)$ & $0.058(10)^{*}$ \\
\hline H1WB & $0.5538(7)$ & $0.690(4)$ & $0.550(3)$ & $0.050(9)^{*}$ \\
\hline $\mathrm{O} 2 \mathrm{~W}$ & 0.500000 & 0.3711 & 0.750000 & $0.0274(5)$ \\
\hline $\mathrm{H} 2 \mathrm{~W}$ & $0.4817(7)$ & $0.305(4)$ & $0.761(4)$ & $0.072(10)^{*}$ \\
\hline $\mathrm{O} 2$ & $0.46352(4)$ & $0.6817(2)$ & $0.57632(18)$ & $0.0327(4)$ \\
\hline $\mathrm{O} 3$ & $0.44216(4)$ & 0.7725 & $0.32901(18)$ & $0.0397(4)$ \\
\hline $\mathrm{C} 8$ & $0.44162(5)$ & $0.7613(3)$ & 0.4833 & $0.0283(5)$ \\
\hline $\mathrm{C} 9$ & $0.41364(5)$ & 0.8469 (4) & 0.5790 & $0.0334(5)$ \\
\hline H9A & 0.405396 & 0.748241 & 0.652987 & $0.040^{*}$ \\
\hline H9B & 0.422184 & 0.951677 & 0.648337 & $0.040^{*}$ \\
\hline N1 & $0.38658(5)$ & 0.9200 & $0.4767(3)$ & $0.0349(5)$ \\
\hline H1 & $0.3849(6)$ & $1.039(4)$ & $0.469(3)$ & $0.037(8)^{*}$ \\
\hline $\mathrm{O} 1$ & $0.36670(5)$ & $0.6242(3)$ & 0.4197 & $0.0629(6)$ \\
\hline $\mathrm{C} 1$ & $0.36437(6)$ & 0.8018 & 0.4068 & $0.0388(6)$ \\
\hline $\mathrm{C} 2$ & $0.33558(6)$ & $0.8888(4)$ & $0.3134(3)$ & $0.0385(6)$ \\
\hline $\mathrm{C} 3$ & $0.31275(8)$ & $0.7639(5)$ & $0.2456(4)$ & $0.0642(9)$ \\
\hline $\mathrm{H} 3$ & 0.316051 & 0.631037 & 0.255105 & $0.077^{*}$ \\
\hline $\mathrm{C} 4$ & $0.28480(8)$ & $0.8330(6)$ & $0.1628(4)$ & $0.0752(11)$ \\
\hline H4 & 0.269374 & 0.746529 & 0.118400 & $0.090 *$ \\
\hline $\mathrm{C} 5$ & $0.27986(7)$ & $1.0263(6)$ & $0.1465(4)$ & $0.0667(10)$ \\
\hline H5 & 0.261079 & 1.073072 & 0.091414 & $0.080^{*}$ \\
\hline C6 & $0.30260(7)$ & $1.1508(5)$ & $0.2113(4)$ & $0.0647(9)$ \\
\hline H6 & 0.299329 & 1.283351 & 0.198759 & $0.078^{*}$ \\
\hline $\mathrm{C} 7$ & $0.33062(7)$ & 1.0849 (4) & $0.2959(4)$ & $0.0499(7)$ \\
\hline $\mathrm{H} 7$ & 0.345894 & 1.172283 & 0.340250 & $0.060 *$ \\
\hline $\mathrm{O} 3 \mathrm{~W}$ & $0.40263(5)$ & $0.3206(3)$ & $0.5364(2)$ & $0.0412(4)$ \\
\hline H3WA & $0.3916(8)$ & $0.420(6)$ & $0.520(4)$ & $0.081(13)^{*}$ \\
\hline
\end{tabular}


Atomic displacement parameters $\left(\AA^{2}\right)$

\begin{tabular}{lllllll}
\hline & $U^{11}$ & $U^{22}$ & $U^{33}$ & $U^{12}$ & $U^{13}$ & $U^{23}$ \\
\hline Co1 & $0.0247(2)$ & $0.0338(2)$ & $0.01649(18)$ & $0.0018(2)$ & $-0.00142(13)$ & $0.00037(17)$ \\
O1W & $0.0350(10)$ & $0.0495(11)$ & $0.0230(9)$ & $-0.0071(8)$ & $-0.0003(7)$ & $-0.0027(8)$ \\
O2W & $0.0294(12)$ & $0.0368(13)$ & $0.0159(10)$ & 0.000 & $0.0003(8)$ & 0.000 \\
O2 & $0.0315(8)$ & $0.0446(10)$ & $0.0216(7)$ & $0.0107(7)$ & $-0.0029(6)$ & $-0.0006(7)$ \\
O3 & $0.0398(9)$ & $0.0569(11)$ & $0.0222(8)$ & $0.0138(9)$ & $-0.0022(7)$ & $0.0012(7)$ \\
C8 & $0.0303(11)$ & $0.0301(12)$ & $0.0241(10)$ & $0.0036(10)$ & $-0.0026(8)$ & $-0.0016(9)$ \\
C9 & $0.0319(12)$ & $0.0397(13)$ & $0.0283(11)$ & $0.0086(10)$ & $-0.0033(9)$ & $-0.0052(10)$ \\
N1 & $0.0309(11)$ & $0.0339(12)$ & $0.0396(12)$ & $0.0079(9)$ & $-0.0028(8)$ & $-0.0026(9)$ \\
O1 & $0.0679(14)$ & $0.0367(11)$ & $0.0820(16)$ & $0.0057(10)$ & $-0.0293(11)$ & $-0.0015(10)$ \\
C1 & $0.0371(13)$ & $0.0404(14)$ & $0.0385(13)$ & $0.0039(12)$ & $-0.0032(10)$ & $-0.0024(11)$ \\
C2 & $0.0320(13)$ & $0.0474(15)$ & $0.0359(13)$ & $0.0030(12)$ & $-0.0002(10)$ & $0.0014(11)$ \\
C3 & $0.0579(19)$ & $0.060(2)$ & $0.072(2)$ & $-0.0079(16)$ & $-0.0251(16)$ & $0.0049(16)$ \\
C4 & $0.0534(19)$ & $0.097(3)$ & $0.073(2)$ & $-0.014(2)$ & $-0.0290(17)$ & $0.007(2)$ \\
C5 & $0.0393(15)$ & $0.105(3)$ & $0.0552(19)$ & $0.0147(19)$ & $-0.0096(13)$ & $0.0112(19)$ \\
C6 & $0.0544(19)$ & $0.070(2)$ & $0.069(2)$ & $0.0216(17)$ & $-0.0092(16)$ & $0.0097(17)$ \\
C7 & $0.0415(15)$ & $0.0540(17)$ & $0.0539(17)$ & $0.0074(14)$ & $-0.0037(12)$ & $0.0005(14)$ \\
O3W & $0.0454(11)$ & $0.0412(11)$ & $0.0368(11)$ & $0.0000(9)$ & $-0.0036(8)$ & $0.0005(8)$ \\
& & & & & &
\end{tabular}

Geometric parameters $\left(\AA,{ }^{\circ}\right)$

\begin{tabular}{llll}
\hline $\mathrm{Co} 1-\mathrm{O} 2$ & $2.0563(15)$ & $\mathrm{N} 1-\mathrm{H} 1$ & $0.83(3)$ \\
$\mathrm{Co} 1-\mathrm{O} 2^{\mathrm{i}}$ & $2.0563(15)$ & $\mathrm{O} 1-\mathrm{C} 1$ & $1.235(3)$ \\
$\mathrm{Co} 1-\mathrm{O} 1 \mathrm{~W}$ & $2.0622(17)$ & $\mathrm{C} 1-\mathrm{C} 2$ & $1.498(3)$ \\
$\mathrm{Co} 1-\mathrm{O} 1 \mathrm{~W}^{\mathrm{i}}$ & $2.0622(17)$ & $\mathrm{C} 2-\mathrm{C} 3$ & $1.370(4)$ \\
$\mathrm{Co} 1-\mathrm{O} 2 \mathrm{~W}^{\mathrm{i}}$ & $2.1899(9)$ & $\mathrm{C} 2-\mathrm{C} 7$ & $1.376(4)$ \\
$\mathrm{Co} 1-\mathrm{O} 2 \mathrm{~W}$ & $2.1899(9)$ & $\mathrm{C} 3-\mathrm{C} 4$ & $1.386(4)$ \\
$\mathrm{O} 1 \mathrm{~W}-\mathrm{H} 1 \mathrm{WA}$ & $0.78(3)$ & $\mathrm{C} 3-\mathrm{H} 3$ & 0.9300 \\
$\mathrm{O} 1 \mathrm{~W}-\mathrm{H} 1 \mathrm{WB}$ & $0.85(3)$ & $\mathrm{C} 4-\mathrm{C} 5$ & $1.357(5)$ \\
$\mathrm{O} 2 \mathrm{~W}-\mathrm{H} 2 \mathrm{~W}$ & $0.88(3)$ & $\mathrm{C} 4-\mathrm{H} 4$ & 0.9300 \\
$\mathrm{O} 2 \mathrm{~W}-\mathrm{H} 2 \mathrm{~W}$ & $\mathrm{C} 5-\mathrm{C} 6$ & $1.356(5)$ \\
$\mathrm{O} 2-\mathrm{C} 8$ & $0.88(3)$ & $\mathrm{C} 5-\mathrm{H} 5$ & 0.9300 \\
$\mathrm{O} 3-\mathrm{C} 8$ & $1.270(2)$ & $\mathrm{C} 6-\mathrm{C} 7$ & $1.387(4)$ \\
$\mathrm{C} 8-\mathrm{C} 9$ & $1.238(2)$ & $\mathrm{C} 6-\mathrm{H} 6$ & 0.9300 \\
$\mathrm{C} 9-\mathrm{N} 1$ & $1.517(3)$ & $\mathrm{C} 7-\mathrm{H} 7$ & 0.9300 \\
$\mathrm{C} 9-\mathrm{H} 9 \mathrm{~A}$ & $1.445(3)$ & $\mathrm{O} 3 \mathrm{~W}-\mathrm{H} 3 \mathrm{WA}$ & $0.84(3)$ \\
$\mathrm{C} 9-\mathrm{H} 9 \mathrm{~B}$ & 0.9700 & & \\
$\mathrm{~N} 1-\mathrm{C} 1$ & 0.9700 & $\mathrm{C} 8-\mathrm{C} 9-\mathrm{H} 9 \mathrm{AB}$ & 108.5 \\
& $1.330(3)$ & $\mathrm{N} 1-\mathrm{C} 9-\mathrm{H} 9 \mathrm{~B}$ & 108.5 \\
$\mathrm{O} 2-\mathrm{Co} 1-\mathrm{O} 2 \mathrm{i}$ & & $\mathrm{C} 8-\mathrm{C} 9-\mathrm{H} 9 \mathrm{~B}$ & 108.5 \\
$\mathrm{O} 2-\mathrm{Co} 1-\mathrm{O} 1 \mathrm{~W}$ & $\mathrm{H} 9 \mathrm{C}-\mathrm{C} 9-\mathrm{H} 9 \mathrm{~B}$ & 107.5 \\
$\mathrm{O} 2 \mathrm{i}-\mathrm{Co} 1-\mathrm{O} 1 \mathrm{~W}$ & $89.40(7)$ & $\mathrm{C} 1-\mathrm{N} 1-\mathrm{C} 9$ & $121.5(2)$ \\
$\mathrm{O} 2-\mathrm{Co} 1-\mathrm{O} 1 \mathrm{~W}^{\mathrm{i}}$ & $90.60(7)$ & &
\end{tabular}




\begin{tabular}{|c|c|c|c|}
\hline $\mathrm{O} 1 \mathrm{~W}-\mathrm{Co} 1-\mathrm{O} 1 \mathrm{~W}^{\mathrm{i}}$ & 180.0 & $\mathrm{C} 1-\mathrm{N} 1-\mathrm{H} 1$ & $121.7(18)$ \\
\hline $\mathrm{O} 2-\mathrm{Co} 1-\mathrm{O} 2 \mathrm{~W}^{\mathrm{i}}$ & $92.59(6)$ & $\mathrm{C} 9-\mathrm{N} 1-\mathrm{H} 1$ & $116.7(18)$ \\
\hline $\mathrm{O} 2-\mathrm{Co} 1-\mathrm{O} 2 \mathrm{~W}^{\mathrm{i}}$ & $87.41(6)$ & $\mathrm{O} 1-\mathrm{C} 1-\mathrm{N} 1$ & $121.7(2)$ \\
\hline $\mathrm{O} 1 \mathrm{~W}-\mathrm{Co} 1-\mathrm{O} 2 \mathrm{~W}^{\mathrm{i}}$ & $90.55(7)$ & $\mathrm{O} 1-\mathrm{C} 1-\mathrm{C} 2$ & $119.8(2)$ \\
\hline $\mathrm{O} 1 \mathrm{~W}^{\mathrm{i}}-\mathrm{Co} 1-\mathrm{O} 2 \mathrm{~W}^{\mathrm{i}}$ & $89.45(7)$ & $\mathrm{N} 1-\mathrm{C} 1-\mathrm{C} 2$ & $118.5(2)$ \\
\hline $\mathrm{O} 2-\mathrm{Co} 1-\mathrm{O} 2 \mathrm{~W}$ & $87.41(6)$ & $\mathrm{C} 3-\mathrm{C} 2-\mathrm{C} 7$ & $118.9(3)$ \\
\hline $\mathrm{O} 22^{\mathrm{i}}-\mathrm{Co} 1-\mathrm{O} 2 \mathrm{~W}$ & $92.59(6)$ & $\mathrm{C} 3-\mathrm{C} 2-\mathrm{C} 1$ & $117.3(2)$ \\
\hline $\mathrm{O} 1 \mathrm{~W}-\mathrm{Co} 1-\mathrm{O} 2 \mathrm{~W}$ & $89.45(7)$ & $\mathrm{C} 7-\mathrm{C} 2-\mathrm{C} 1$ & $123.8(2)$ \\
\hline $\mathrm{O} 1 \mathrm{~W}-\mathrm{Co} 1-\mathrm{O} 2 \mathrm{~W}$ & $90.55(7)$ & $\mathrm{C} 2-\mathrm{C} 3-\mathrm{C} 4$ & $120.8(3)$ \\
\hline $\mathrm{O} 2 \mathrm{~W}^{\mathrm{i}}-\mathrm{Co} 1-\mathrm{O} 2 \mathrm{~W}$ & 180.0 & $\mathrm{C} 2-\mathrm{C} 3-\mathrm{H} 3$ & 119.6 \\
\hline $\mathrm{Co} 1-\mathrm{O} 1 \mathrm{~W}-\mathrm{H} 1 \mathrm{WA}$ & $109(2)$ & $\mathrm{C} 4-\mathrm{C} 3-\mathrm{H} 3$ & 119.6 \\
\hline $\mathrm{Co} 1-\mathrm{O} 1 \mathrm{~W}-\mathrm{H} 1 \mathrm{WB}$ & $118.5(19)$ & $\mathrm{C} 5-\mathrm{C} 4-\mathrm{C} 3$ & $120.2(3)$ \\
\hline $\mathrm{H} 1 \mathrm{WA}-\mathrm{O} 1 \mathrm{~W}-\mathrm{H} 1 \mathrm{WB}$ & $110(3)$ & $\mathrm{C} 5-\mathrm{C} 4-\mathrm{H} 4$ & 119.9 \\
\hline $\mathrm{Co} 1 \mathrm{ii}-\mathrm{O} 2 \mathrm{~W}-\mathrm{Co} 1$ & $132.03(11)$ & $\mathrm{C} 3-\mathrm{C} 4-\mathrm{H} 4$ & 119.9 \\
\hline $\mathrm{Co}^{\mathrm{ii}}-\mathrm{O} 2 \mathrm{~W}-\mathrm{H} 2 \mathrm{~W}$ & $95(2)$ & $\mathrm{C} 6-\mathrm{C} 5-\mathrm{C} 4$ & $119.3(3)$ \\
\hline $\mathrm{Co} 1-\mathrm{O} 2 \mathrm{~W}-\mathrm{H} 2 \mathrm{~W}$ & $109(2)$ & $\mathrm{C} 6-\mathrm{C} 5-\mathrm{H} 5$ & 120.3 \\
\hline $\mathrm{Co} 1^{\mathrm{ii}}-\mathrm{O} 2 \mathrm{~W}-\mathrm{H} 2 \mathrm{~W}^{\mathrm{ii}}$ & $109(2)$ & $\mathrm{C} 4-\mathrm{C} 5-\mathrm{H} 5$ & 120.3 \\
\hline $\mathrm{Co} 1-\mathrm{O} 2 \mathrm{~W}-\mathrm{H} 2 \mathrm{~W}^{\mathrm{ii}}$ & $95(2)$ & $\mathrm{C} 5-\mathrm{C} 6-\mathrm{C} 7$ & $121.5(3)$ \\
\hline $\mathrm{H} 2 \mathrm{~W}-\mathrm{O} 2 \mathrm{~W}-\mathrm{H} 2 \mathrm{~W}^{\mathrm{ii}}$ & $118(4)$ & $\mathrm{C} 5-\mathrm{C} 6-\mathrm{H} 6$ & 119.3 \\
\hline $\mathrm{C} 8-\mathrm{O} 2-\mathrm{Co} 1$ & $126.39(14)$ & $\mathrm{C} 7-\mathrm{C} 6-\mathrm{H} 6$ & 119.3 \\
\hline $\mathrm{O} 3-\mathrm{C} 8-\mathrm{O} 2$ & $125.2(2)$ & $\mathrm{C} 2-\mathrm{C} 7-\mathrm{C} 6$ & $119.3(3)$ \\
\hline $\mathrm{O} 3-\mathrm{C} 8-\mathrm{C} 9$ & $121.20(19)$ & $\mathrm{C} 2-\mathrm{C} 7-\mathrm{H} 7$ & 120.4 \\
\hline $\mathrm{O} 2-\mathrm{C} 8-\mathrm{C} 9$ & $113.61(18)$ & $\mathrm{C} 6-\mathrm{C} 7-\mathrm{H} 7$ & 120.4 \\
\hline $\mathrm{N} 1-\mathrm{C} 9-\mathrm{C} 8$ & $115.14(18)$ & $\mathrm{H} 3 \mathrm{WA}-\mathrm{O} 3 \mathrm{~W}-\mathrm{H} 3 \mathrm{WB}$ & $108(3)$ \\
\hline $\mathrm{N} 1-\mathrm{C} 9-\mathrm{H} 9 \mathrm{~A}$ & 108.5 & & \\
\hline $\mathrm{Co} 1-\mathrm{O} 2-\mathrm{C} 8-\mathrm{O} 3$ & $-14.5(3)$ & $\mathrm{N} 1-\mathrm{C} 1-\mathrm{C} 2-\mathrm{C} 7$ & $-0.2(4)$ \\
\hline $\mathrm{Co} 1-\mathrm{O} 2-\mathrm{C} 8-\mathrm{C} 9$ & $166.03(14)$ & $\mathrm{C} 7-\mathrm{C} 2-\mathrm{C} 3-\mathrm{C} 4$ & $-1.1(5)$ \\
\hline $\mathrm{O} 3-\mathrm{C} 8-\mathrm{C} 9-\mathrm{N} 1$ & $6.9(3)$ & $\mathrm{C} 1-\mathrm{C} 2-\mathrm{C} 3-\mathrm{C} 4$ & $177.5(3)$ \\
\hline $\mathrm{O} 2-\mathrm{C} 8-\mathrm{C} 9-\mathrm{N} 1$ & $-173.6(2)$ & $\mathrm{C} 2-\mathrm{C} 3-\mathrm{C} 4-\mathrm{C} 5$ & $0.7(6)$ \\
\hline $\mathrm{C} 8-\mathrm{C} 9-\mathrm{N} 1-\mathrm{C} 1$ & $78.1(3)$ & $\mathrm{C} 3-\mathrm{C} 4-\mathrm{C} 5-\mathrm{C} 6$ & $0.3(6)$ \\
\hline $\mathrm{C} 9-\mathrm{N} 1-\mathrm{C} 1-\mathrm{O} 1$ & $-3.4(4)$ & $\mathrm{C} 4-\mathrm{C} 5-\mathrm{C} 6-\mathrm{C} 7$ & $-0.8(5)$ \\
\hline $\mathrm{C} 9-\mathrm{N} 1-\mathrm{C} 1-\mathrm{C} 2$ & $175.3(2)$ & $\mathrm{C} 3-\mathrm{C} 2-\mathrm{C} 7-\mathrm{C} 6$ & $0.5(4)$ \\
\hline $\mathrm{O} 1-\mathrm{C} 1-\mathrm{C} 2-\mathrm{C} 3$ & $0.0(4)$ & $\mathrm{C} 1-\mathrm{C} 2-\mathrm{C} 7-\mathrm{C} 6$ & $-178.0(3)$ \\
\hline $\mathrm{N} 1-\mathrm{C} 1-\mathrm{C} 2-\mathrm{C} 3$ & $-178.7(3)$ & $\mathrm{C} 5-\mathrm{C} 6-\mathrm{C} 7-\mathrm{C} 2$ & $0.5(5)$ \\
\hline $\mathrm{O} 1-\mathrm{C} 1-\mathrm{C} 2-\mathrm{C} 7$ & $178.5(3)$ & & \\
\hline
\end{tabular}

Symmetry codes: (i) $-x+1,-y+1,-z+1$; (ii) $-x+1, y,-z+3 / 2$.

Hydrogen-bond geometry $\left(A,{ }^{\circ}\right)$

\begin{tabular}{lllll}
\hline$D-\mathrm{H} \cdots A$ & $D-\mathrm{H}$ & $\mathrm{H} \cdots A$ & $D \cdots A$ & $D-\mathrm{H} \cdots A$ \\
\hline $\mathrm{O} 1 W-\mathrm{H} 1 W A \cdots \mathrm{O} 2^{\mathrm{ii}}$ & $0.78(3)$ & $1.93(3)$ & $2.714(2)$ & $176(3)$ \\
$\mathrm{O} 1 W-\mathrm{H} 1 W B \cdots \mathrm{O} 3 W^{\mathrm{i}}$ & $0.85(3)$ & $1.93(3)$ & $2.780(3)$ & $178(3)$ \\
$\mathrm{O} 2 W-\mathrm{H} 2 W \cdots \mathrm{O} 3^{\mathrm{iii}}$ & $0.88(3)$ & $1.80(3)$ & $2.6576(18)$ & $163(3)$ \\
$\mathrm{C} 9-\mathrm{H} 9 B \cdots \mathrm{O} 3^{\text {iv }}$ & 0.97 & 2.51 & $3.481(3)$ & 178 \\
$\mathrm{~N} 1-\mathrm{H} 1 \cdots \mathrm{O} 3 W^{v}$ & $0.83(3)$ & $2.13(3)$ & $2.880(3)$ & $149(2)$
\end{tabular}




$\begin{array}{llllr}\mathrm{O} 3 W-\mathrm{H} 3 W A \cdots \mathrm{O} 1 & 0.83(4) & 1.90(4) & 2.708(3) & 164(3) \\ \mathrm{O} 3 W-\mathrm{H} 3 W B \cdots \mathrm{O} 3^{\text {iii }} & 0.84(3) & 2.12(3) & 2.873(3) & 149(3)\end{array}$

Symmetry codes: (i) $-x+1,-y+1,-z+1$; (ii) $-x+1, y,-z+3 / 2$; (iii) $x,-y+1, z+1 / 2$; (iv) $x,-y+2, z+1 / 2$; (v) $x, y+1, z$.

catena-Poly[[[diaquabis(N-benzoylglycinato)nickel(II)]- $\mu$-aqua] dihydrate] (2)

Crystal data

$\left[\mathrm{Ni}\left(\mathrm{C}_{9} \mathrm{H}_{8} \mathrm{NO}_{3}\right)_{2}\left(\mathrm{H}_{2} \mathrm{O}\right)_{3}\right] \cdot 2 \mathrm{H}_{2} \mathrm{O}$

$M_{r}=505.12$

Monoclinic, $C 2 / c$

$a=40.884(4) \AA$

$b=6.9438(8) \AA$

$c=7.8983(8) \AA$

$\beta=91.900(2)^{\circ}$

$V=2241.0(4) \AA^{3}$

$Z=4$

$F(000)=1056$

$D_{\mathrm{x}}=1.497 \mathrm{Mg} \mathrm{m}^{-3}$

Mo $K \alpha$ radiation, $\lambda=0.71073 \AA$

Cell parameters from 8047 reflections

$\theta=3.0-30.5^{\circ}$

$\mu=0.93 \mathrm{~mm}^{-1}$

$T=293 \mathrm{~K}$

Plate, green

$0.29 \times 0.24 \times 0.05 \mathrm{~mm}$

\section{Data collection}

Bruker D8 Quest Eco diffractometer

Radiation source: Sealed Tube $\varphi$ and $\omega$ scans

Absorption correction: numerical

(SADABS; Krause et al., 2015)

$T_{\min }=0.608, T_{\max }=0.746$

17095 measured reflections

$$
\begin{aligned}
& 3392 \text { independent reflections } \\
& 2995 \text { reflections with } I>2 \sigma(I) \\
& R_{\text {int }}=0.036 \\
& \theta_{\max }=30.5^{\circ}, \theta_{\min }=3.0^{\circ} \\
& h=-58 \rightarrow 58 \\
& k=-9 \rightarrow 9 \\
& l=-11 \rightarrow 11
\end{aligned}
$$

\section{Refinement}

Refinement on $F^{2}$

Least-squares matrix: full

$R\left[F^{2}>2 \sigma\left(F^{2}\right)\right]=0.056$

$w R\left(F^{2}\right)=0.151$

$S=1.15$

3392 reflections

174 parameters

0 restraints

Hydrogen site location: mixed

$\mathrm{H}$ atoms treated by a mixture of independent

and constrained refinement

$$
w=1 /\left[\sigma^{2}\left(F_{\mathrm{o}}^{2}\right)+(0.0534 P)^{2}+10.915 P\right]
$$

where $P=\left(F_{\mathrm{o}}^{2}+2 F_{\mathrm{c}}^{2}\right) / 3$

$(\Delta / \sigma)_{\max }<0.001$

$\Delta \rho_{\max }=1.24 \mathrm{e} \AA^{-3}$

$\Delta \rho_{\min }=-0.75$ e $\AA^{-3}$

Special details

Geometry. All esds (except the esd in the dihedral angle between two 1.s. planes) are estimated using the full covariance matrix. The cell esds are taken into account individually in the estimation of esds in distances, angles and torsion angles; correlations between esds in cell parameters are only used when they are defined by crystal symmetry. An approximate (isotropic) treatment of cell esds is used for estimating esds involving l.s. planes.

Fractional atomic coordinates and isotropic or equivalent isotropic displacement parameters $\left(\AA^{2}\right)$

\begin{tabular}{lllll}
\hline & $x$ & $y$ & $z$ & $U_{\text {iso }} * / U_{\text {eq }}$ \\
\hline Ni1 & 0.500000 & 0.500000 & 0.500000 & $0.01759(14)$ \\
O1W & $0.46631(6)$ & $0.6995(4)$ & $0.4192(3)$ & $0.0285(4)$ \\
H1WA & $0.4671(12)$ & $0.696(8)$ & $0.305(7)$ & $0.058(14)^{*}$ \\
H1WB & $0.4475(12)$ & $0.690(7)$ & $0.447(6)$ & $0.043(12)^{*}$ \\
O2W & 0.500000 & $0.3793(4)$ & 0.250000 & $0.0202(5)$ \\
H2W & $0.4841(9)$ & $0.322(6)$ & $0.263(5)$ & $0.034(11)^{*}$
\end{tabular}




$\begin{array}{lllll}\text { O2 } & 0.53585(5) & 0.6801(3) & 0.4257(2) & 0.0268(4) \\ \text { O3 } & 0.55711(6) & 0.7689(4) & 0.6765(3) & 0.0351(5) \\ \text { C8 } & 0.55754(7) & 0.7599(4) & 0.5190(3) & 0.0226(5) \\ \text { C9 } & 0.58529(8) & 0.8493(5) & 0.4233(4) & 0.0300(6) \\ \text { H9A } & 0.593708 & 0.753037 & 0.347050 & 0.036^{*} \\ \text { H9B } & 0.576431 & 0.953631 & 0.354201 & 0.036^{*} \\ \text { N1 } & 0.61229(6) & 0.9234(4) & 0.5260(4) & 0.0309(5) \\ \text { H1 } & 0.6146(12) & 1.056(8) & 0.526(6) & 0.049(13)^{*} \\ \text { O1 } & 0.63274(9) & 0.6289(4) & 0.5816(5) & 0.0642(10) \\ \text { C1 } & 0.63502(8) & 0.8063(5) & 0.5955(4) & 0.0353(7) \\ \text { C2 } & 0.66370(8) & 0.8938(6) & 0.6870(5) & 0.0379(7) \\ \text { C3 } & 0.68705(12) & 0.7700(8) & 0.7561(6) & 0.0591(12) \\ \text { H3 } & 0.683771 & 0.637691 & 0.748942 & 0.071^{*} \\ \text { C4 } & 0.71526(13) & 0.8407(11) & 0.8360(7) & 0.0746(17) \\ \text { H4 } & 0.731124 & 0.755654 & 0.877935 & 0.090^{*} \\ \text { C5 } & 0.71989(12) & 1.0344(10) & 0.8535(7) & 0.0687(16) \\ \text { H5 } & 0.738643 & 1.081793 & 0.908817 & 0.082^{*} \\ \text { C6 } & 0.69707(12) & 1.1556(8) & 0.7899(6) & 0.0602(12) \\ \text { H6 } & 0.700203 & 1.287520 & 0.802593 & 0.072^{*} \\ \text { C7 } & 0.66879(10) & 1.0893(7) & 0.7054(6) & 0.0501(10) \\ \text { H7 } & 0.653429 & 1.176328 & 0.661677 & 0.060^{*} \\ \text { O3W } & 0.59732(7) & 0.3249(4) & 0.4678(4) & 0.0389(6) \\ \text { H3WB } & 0.5916(14) & 0.323(9) & 0.362(8) & 0.076(19)^{*} \\ \text { H3WA } & 0.611(2) & 0.407(13) & 0.485(11) & 0.12(3)^{*} \\ & & & & \end{array}$

Atomic displacement parameters $\left(\AA^{2}\right)$

\begin{tabular}{lllllll}
\hline & $U^{11}$ & $U^{22}$ & $U^{33}$ & $U^{12}$ & $U^{13}$ & $U^{23}$ \\
\hline Ni1 & $0.0173(2)$ & $0.0246(2)$ & $0.01079(19)$ & $-0.00141(17)$ & $-0.00075(14)$ & $-0.00031(17)$ \\
O1W & $0.0269(10)$ & $0.0380(12)$ & $0.0204(9)$ & $0.0067(9)$ & $-0.0004(8)$ & $0.0033(8)$ \\
O2W & $0.0212(13)$ & $0.0262(13)$ & $0.0132(11)$ & 0.000 & $-0.0013(9)$ & 0.000 \\
O2 & $0.0246(9)$ & $0.0393(12)$ & $0.0164(8)$ & $-0.0116(8)$ & $-0.0010(7)$ & $0.0008(8)$ \\
O3 & $0.0328(11)$ & $0.0521(15)$ & $0.0204(9)$ & $-0.0160(10)$ & $-0.0010(8)$ & $-0.0017(9)$ \\
C8 & $0.0221(12)$ & $0.0246(12)$ & $0.0211(11)$ & $-0.0038(9)$ & $-0.0002(9)$ & $0.0029(10)$ \\
C9 & $0.0283(14)$ & $0.0373(16)$ & $0.0242(12)$ & $-0.0099(12)$ & $-0.0006(10)$ & $0.0052(12)$ \\
N1 & $0.0246(12)$ & $0.0318(13)$ & $0.0360(13)$ & $-0.0082(10)$ & $-0.0012(10)$ & $0.0031(11)$ \\
O1 & $0.067(2)$ & $0.0349(15)$ & $0.089(3)$ & $-0.0063(14)$ & $-0.0317(18)$ & $0.0038(15)$ \\
C1 & $0.0331(16)$ & $0.0359(17)$ & $0.0367(16)$ & $-0.0054(13)$ & $-0.0027(13)$ & $0.0024(13)$ \\
C2 & $0.0294(15)$ & $0.049(2)$ & $0.0352(16)$ & $-0.0032(14)$ & $-0.0019(12)$ & $-0.0030(15)$ \\
C3 & $0.055(3)$ & $0.057(3)$ & $0.064(3)$ & $0.008(2)$ & $-0.020(2)$ & $-0.005(2)$ \\
C4 & $0.047(3)$ & $0.104(5)$ & $0.071(3)$ & $0.018(3)$ & $-0.025(2)$ & $-0.006(3)$ \\
C5 & $0.039(2)$ & $0.108(5)$ & $0.058(3)$ & $-0.020(3)$ & $-0.010(2)$ & $-0.014(3)$ \\
C6 & $0.053(3)$ & $0.065(3)$ & $0.062(3)$ & $-0.024(2)$ & $-0.009(2)$ & $-0.004(2)$ \\
C7 & $0.0386(19)$ & $0.054(2)$ & $0.057(2)$ & $-0.0104(18)$ & $-0.0091(17)$ & $-0.002(2)$ \\
O3W & $0.0391(13)$ & $0.0405(14)$ & $0.0367(13)$ & $-0.0001(11)$ & $-0.0027(10)$ & $-0.0007(11)$ \\
& & & & & & \\
\hline
\end{tabular}


Geometric parameters $\left(\AA,{ }^{\circ}\right)$

\begin{tabular}{|c|c|c|c|}
\hline $\mathrm{Ni} 1-\mathrm{O} 2^{\mathrm{i}}$ & $2.029(2)$ & $\mathrm{N} 1-\mathrm{H} 1$ & $0.93(5)$ \\
\hline $\mathrm{Ni} 1-\mathrm{O} 2$ & $2.029(2)$ & $\mathrm{O} 1-\mathrm{C} 1$ & $1.240(5)$ \\
\hline $\mathrm{Ni} 1-\mathrm{O}_{1} \mathrm{~W}^{\mathrm{i}}$ & $2.041(2)$ & $\mathrm{C} 1-\mathrm{C} 2$ & $1.487(5)$ \\
\hline Ni1-O1W & $2.041(2)$ & $\mathrm{C} 2-\mathrm{C} 7$ & $1.380(6)$ \\
\hline $\mathrm{Ni} 1-\mathrm{O} 2 \mathrm{~W}^{\mathrm{i}}$ & $2.1450(12)$ & $\mathrm{C} 2-\mathrm{C} 3$ & $1.384(6)$ \\
\hline $\mathrm{Ni} 1-\mathrm{O} 2 \mathrm{~W}$ & $2.1450(12)$ & $\mathrm{C} 3-\mathrm{C} 4$ & $1.386(7)$ \\
\hline $\mathrm{O} 1 \mathrm{~W}-\mathrm{H} 1 \mathrm{WA}$ & $0.90(5)$ & $\mathrm{C} 3-\mathrm{H} 3$ & 0.9300 \\
\hline $\mathrm{O} 1 \mathrm{~W}-\mathrm{H} 1 \mathrm{WB}$ & $0.81(5)$ & $\mathrm{C} 4-\mathrm{C} 5$ & $1.364(9)$ \\
\hline $\mathrm{O} 2 \mathrm{~W}-\mathrm{H} 2 \mathrm{~W}$ & $0.77(4)$ & $\mathrm{C} 4-\mathrm{H} 4$ & 0.9300 \\
\hline $\mathrm{O} 2 \mathrm{~W}-\mathrm{H} 2 \mathrm{~W}^{\mathrm{ii}}$ & $0.77(4)$ & $\mathrm{C} 5-\mathrm{C} 6$ & $1.342(8)$ \\
\hline $\mathrm{O} 2-\mathrm{C} 8$ & $1.262(3)$ & $\mathrm{C} 5-\mathrm{H} 5$ & 0.9300 \\
\hline $\mathrm{O} 3-\mathrm{C} 8$ & $1.246(3)$ & $\mathrm{C} 6-\mathrm{C} 7$ & $1.394(6)$ \\
\hline $\mathrm{C} 8-\mathrm{C} 9$ & $1.517(4)$ & $\mathrm{C} 6-\mathrm{H} 6$ & 0.9300 \\
\hline $\mathrm{C} 9-\mathrm{N} 1$ & $1.443(4)$ & $\mathrm{C} 7-\mathrm{H} 7$ & 0.9300 \\
\hline C9-H9A & 0.9700 & $\mathrm{O} 3 \mathrm{~W}-\mathrm{H} 3 \mathrm{WB}$ & $0.86(6)$ \\
\hline C9-H9B & 0.9700 & $\mathrm{O} 3 \mathrm{~W}-\mathrm{H} 3 \mathrm{WA}$ & $0.81(9)$ \\
\hline $\mathrm{N} 1-\mathrm{C} 1$ & $1.338(5)$ & & \\
\hline $\mathrm{O} 2 \mathrm{i}-\mathrm{Ni} 1-\mathrm{O} 2$ & $180.00(12)$ & $\mathrm{C} 8-\mathrm{C} 9-\mathrm{H} 9 \mathrm{~A}$ & 108.3 \\
\hline $\mathrm{O} 2^{\mathrm{i}}-\mathrm{Ni} 1-\mathrm{O} 1 \mathrm{~W}^{\mathrm{i}}$ & $88.72(10)$ & $\mathrm{N} 1-\mathrm{C} 9-\mathrm{H} 9 \mathrm{~B}$ & 108.3 \\
\hline $\mathrm{O} 2-\mathrm{Ni} 1-\mathrm{O} 1 \mathrm{~W}^{\mathrm{i}}$ & $91.28(10)$ & $\mathrm{C} 8-\mathrm{C} 9-\mathrm{H} 9 \mathrm{~B}$ & 108.3 \\
\hline $\mathrm{O} 2^{\mathrm{i}}-\mathrm{Ni} 1-\mathrm{O} 1 \mathrm{~W}$ & $91.28(10)$ & $\mathrm{H} 9 \mathrm{~A}-\mathrm{C} 9-\mathrm{H} 9 \mathrm{~B}$ & 107.4 \\
\hline $\mathrm{O} 2-\mathrm{Ni1}-\mathrm{O} 1 \mathrm{~W}$ & $88.72(10)$ & $\mathrm{C} 1-\mathrm{N} 1-\mathrm{C} 9$ & $121.4(3)$ \\
\hline $\mathrm{O} 1 \mathrm{~W}-\mathrm{Ni} 1-\mathrm{O} 1 \mathrm{~W}$ & 180.0 & $\mathrm{C} 1-\mathrm{N} 1-\mathrm{H} 1$ & $122(3)$ \\
\hline $\mathrm{O} 2^{\mathrm{i}}-\mathrm{Ni} 1-\mathrm{O} 2 \mathrm{~W}^{\mathrm{i}}$ & $87.27(8)$ & $\mathrm{C} 9-\mathrm{N} 1-\mathrm{H} 1$ & $116(3)$ \\
\hline $\mathrm{O} 2-\mathrm{Ni} 1-\mathrm{O} 2 \mathrm{~W}^{\mathrm{i}}$ & $92.73(8)$ & $\mathrm{O} 1-\mathrm{C} 1-\mathrm{N} 1$ & $121.2(3)$ \\
\hline $\mathrm{O} 1 \mathrm{~W}^{\mathrm{i}}-\mathrm{Ni} 1-\mathrm{O} 2 \mathrm{~W}^{\mathrm{i}}$ & $89.87(8)$ & $\mathrm{O} 1-\mathrm{C} 1-\mathrm{C} 2$ & $120.3(3)$ \\
\hline $\mathrm{O} 1 \mathrm{~W}-\mathrm{Ni} 1-\mathrm{O} 2 \mathrm{~W}^{\mathrm{i}}$ & $90.13(8)$ & $\mathrm{N} 1-\mathrm{C} 1-\mathrm{C} 2$ & $118.5(3)$ \\
\hline $\mathrm{O} 2^{\mathrm{i}}-\mathrm{Ni} 1-\mathrm{O} 2 \mathrm{~W}$ & $92.73(8)$ & $\mathrm{C} 7-\mathrm{C} 2-\mathrm{C} 3$ & $118.0(4)$ \\
\hline $\mathrm{O} 2-\mathrm{Ni1}-\mathrm{O} 2 \mathrm{~W}$ & $87.27(8)$ & $\mathrm{C} 7-\mathrm{C} 2-\mathrm{C} 1$ & $124.6(4)$ \\
\hline $\mathrm{O} 1 \mathrm{~W}-\mathrm{Ni} 1-\mathrm{O} 2 \mathrm{~W}$ & $90.13(8)$ & $\mathrm{C} 3-\mathrm{C} 2-\mathrm{C} 1$ & $117.4(4)$ \\
\hline $\mathrm{O} 1 \mathrm{~W}-\mathrm{Ni1}-\mathrm{O} 2 \mathrm{~W}$ & $89.87(8)$ & $\mathrm{C} 2-\mathrm{C} 3-\mathrm{C} 4$ & $120.8(5)$ \\
\hline $\mathrm{O} 2 \mathrm{~W}^{\mathrm{i}}-\mathrm{Ni} 1-\mathrm{O} 2 \mathrm{~W}$ & 180.0 & $\mathrm{C} 2-\mathrm{C} 3-\mathrm{H} 3$ & 119.6 \\
\hline $\mathrm{Ni1}-\mathrm{O} 1 \mathrm{~W}-\mathrm{H} 1 \mathrm{WA}$ & $104(3)$ & $\mathrm{C} 4-\mathrm{C} 3-\mathrm{H} 3$ & 119.6 \\
\hline Ni1-O1W-H1WB & $120(3)$ & $\mathrm{C} 5-\mathrm{C} 4-\mathrm{C} 3$ & $120.4(5)$ \\
\hline $\mathrm{H} 1 \mathrm{WA}-\mathrm{O} 1 \mathrm{~W}-\mathrm{H} 1 \mathrm{WB}$ & $109(4)$ & $\mathrm{C} 5-\mathrm{C} 4-\mathrm{H} 4$ & 119.8 \\
\hline $\mathrm{Ni} 1-\mathrm{O} 2 \mathrm{~W}-\mathrm{Ni1}{ }^{\mathrm{ii}}$ & $134.02(15)$ & $\mathrm{C} 3-\mathrm{C} 4-\mathrm{H} 4$ & 119.8 \\
\hline $\mathrm{Ni} 1-\mathrm{O} 2 \mathrm{~W}-\mathrm{H} 2 \mathrm{~W}$ & $93(3)$ & $\mathrm{C} 6-\mathrm{C} 5-\mathrm{C} 4$ & $119.2(4)$ \\
\hline $\mathrm{Ni} 1^{\mathrm{ii}}-\mathrm{O} 2 \mathrm{~W}-\mathrm{H} 2 \mathrm{~W}$ & $111(3)$ & $\mathrm{C} 6-\mathrm{C} 5-\mathrm{H} 5$ & 120.4 \\
\hline $\mathrm{Ni} 1-\mathrm{O} 2 \mathrm{~W}-\mathrm{H} 2 \mathrm{~W}^{\mathrm{ii}}$ & $111(3)$ & $\mathrm{C} 4-\mathrm{C} 5-\mathrm{H} 5$ & 120.4 \\
\hline $\mathrm{Ni} 1^{1 i}-\mathrm{O} 2 \mathrm{~W}-\mathrm{H} 2 \mathrm{~W}^{\mathrm{ii}}$ & $93(3)$ & $\mathrm{C} 5-\mathrm{C} 6-\mathrm{C} 7$ & $121.8(5)$ \\
\hline $\mathrm{H} 2 \mathrm{~W}-\mathrm{O} 2 \mathrm{~W}-\mathrm{H} 2 \mathrm{~W}^{\mathrm{ii}}$ & $118(6)$ & $\mathrm{C} 5-\mathrm{C} 6-\mathrm{H} 6$ & 119.1 \\
\hline $\mathrm{C} 8-\mathrm{O} 2-\mathrm{Ni} 1$ & $127.02(18)$ & $\mathrm{C} 7-\mathrm{C} 6-\mathrm{H} 6$ & 119.1 \\
\hline $\mathrm{O} 3-\mathrm{C} 8-\mathrm{O} 2$ & $124.9(3)$ & $\mathrm{C} 2-\mathrm{C} 7-\mathrm{C} 6$ & $119.7(4)$ \\
\hline $\mathrm{O} 3-\mathrm{C} 8-\mathrm{C} 9$ & $120.8(2)$ & $\mathrm{C} 2-\mathrm{C} 7-\mathrm{H} 7$ & 120.2 \\
\hline $\mathrm{O} 2-\mathrm{C} 8-\mathrm{C} 9$ & $114.3(2)$ & $\mathrm{C} 6-\mathrm{C} 7-\mathrm{H} 7$ & 120.2 \\
\hline
\end{tabular}




$\begin{array}{llll}\mathrm{N} 1-\mathrm{C} 9-\mathrm{C} 8 & 115.9(2) & \mathrm{H} 3 \mathrm{WB}-\mathrm{O} 3 \mathrm{~W}-\mathrm{H} 3 \mathrm{WA} & 110(7) \\ \mathrm{N} 1-\mathrm{C} 9-\mathrm{H} 9 \mathrm{~A} & 108.3 & & \\ \mathrm{Ni1}-\mathrm{O} 2-\mathrm{C} 8-\mathrm{O} 3 & -13.6(5) & \mathrm{N} 1-\mathrm{C} 1-\mathrm{C} 2-\mathrm{C} 3 & -179.3(4) \\ \mathrm{Ni} 1-\mathrm{O} 2-\mathrm{C} 8-\mathrm{C} 9 & 166.8(2) & \mathrm{C} 7-\mathrm{C} 2-\mathrm{C} 3-\mathrm{C} 4 & -2.3(8) \\ \mathrm{O} 3-\mathrm{C} 8-\mathrm{C} 9-\mathrm{N} 1 & 6.8(5) & \mathrm{C} 1-\mathrm{C} 2-\mathrm{C} 3-\mathrm{C} 4 & 176.8(5) \\ \mathrm{O} 2-\mathrm{C} 8-\mathrm{C} 9-\mathrm{N} 1 & -173.5(3) & \mathrm{C} 2-\mathrm{C} 3-\mathrm{C} 4-\mathrm{C} 5 & 2.5(9) \\ \mathrm{C} 8-\mathrm{C} 9-\mathrm{N} 1-\mathrm{C} 1 & 78.0(4) & \mathrm{C} 3-\mathrm{C} 4-\mathrm{C} 5-\mathrm{C} 6 & -1.1(9) \\ \mathrm{C} 9-\mathrm{N} 1-\mathrm{C} 1-\mathrm{O} 1 & -3.9(6) & \mathrm{C} 4-\mathrm{C} 5-\mathrm{C} 6-\mathrm{C} 7 & 0.8(7) \\ \mathrm{C} 9-\mathrm{N} 1-\mathrm{C} 1-\mathrm{C} 2 & 174.6(3) & \mathrm{C} 3-\mathrm{C} 2-\mathrm{C} 7-\mathrm{C} 6 & -178.2(4) \\ \mathrm{O} 1-\mathrm{C} 1-\mathrm{C} 2-\mathrm{C} 7 & 178.3(4) & \mathrm{C} 1-\mathrm{C} 2-\mathrm{C} 7-\mathrm{C} 6 & 0.5(8) \\ \mathrm{N} 1-\mathrm{C} 1-\mathrm{C} 2-\mathrm{C} 7 & -0.2(6) & \mathrm{C} 5-\mathrm{C} 6-\mathrm{C} 7-\mathrm{C} 2 & \\ \mathrm{O} 1-\mathrm{C} 1-\mathrm{C} 2-\mathrm{C} 3 & -0.7(6) & & \end{array}$

Symmetry codes: (i) $-x+1,-y+1,-z+1$; (ii) $-x+1, y,-z+1 / 2$.

Hydrogen-bond geometry $\left(\AA,{ }^{\circ}\right)$

\begin{tabular}{lllll}
\hline$D-\mathrm{H} \cdots A$ & $D-\mathrm{H}$ & $\mathrm{H} \cdots A$ & $D \cdots A$ & $D-\mathrm{H} \cdots A$ \\
\hline $\mathrm{O} 1 W-\mathrm{H} 1 W A \cdots \mathrm{O} 2^{\mathrm{ii}}$ & $0.90(5)$ & $1.82(5)$ & $2.726(3)$ & $174(5)$ \\
$\mathrm{O} 1 W-\mathrm{H} 1 W B \cdots \mathrm{O} 3 W^{\mathrm{j}}$ & $0.81(5)$ & $1.97(5)$ & $2.783(4)$ & $176(5)$ \\
$\mathrm{O} 2 W-\mathrm{H} 2 W \cdots 3^{\mathrm{i}}$ & $0.77(4)$ & $1.88(4)$ & $2.634(3)$ & $167(4)$ \\
$\mathrm{C} 9-\mathrm{H} 9 B \cdots 3^{\mathrm{iii}}$ & 0.97 & 2.50 & $3.465(4)$ & 176 \\
$\mathrm{~N} 1-\mathrm{H} 1 \cdots \mathrm{O} 3 W^{\mathrm{iv}}$ & $0.93(5)$ & $2.04(5)$ & $2.888(4)$ & $151(4)$ \\
$\mathrm{O} 3 W-\mathrm{H} 3 W B \cdots 3^{\mathrm{v}}$ & $0.86(6)$ & $2.10(6)$ & $2.858(4)$ & $147(5)$ \\
$\mathrm{O} 3 W-\mathrm{H} 3 W A \cdots \mathrm{O} 1$ & $0.81(9)$ & $1.92(9)$ & $2.697(4)$ & $159(8)$
\end{tabular}

Symmetry codes: (i) $-x+1,-y+1,-z+1$; (ii) $-x+1, y,-z+1 / 2$; (iii) $x,-y+2, z-1 / 2$; (iv) $x, y+1, z$; (v) $x,-y+1, z-1 / 2$. 